ARGONNE NATIONAL LABORATORY

9700 South Cass Avenue, Argonne, Illinois 60439

ANL/EES-TM-377

\title{
DETERMINATION OF ECOLOGICALLY VITAL GROUNDWATERS AT SELECTED SITES IN \\ THE FORMERLY UTILIZED SITES \\ REMEDIAL ACTION PROGRAM
}

ANL/EES-TM--377

DE89 015642

\begin{abstract}
by
William S. Vinikour and Stephen C.L. Yin

Energy and Environmental Systems Division
\end{abstract}

August 1989

work sponsored by

U.S. DEPARTMENT OF ENERGY

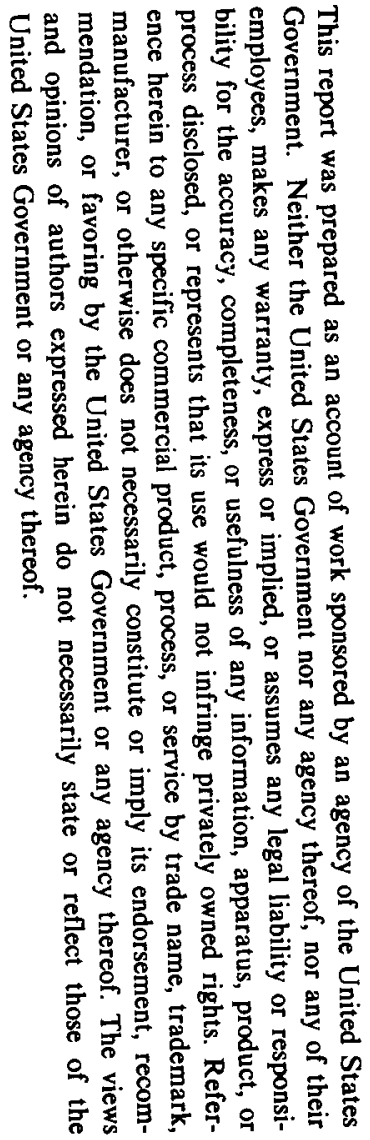

Oak Ridge Operations Office

Oak Ridge, Tennessee 


\section{DISCLAIMER}

This report was prepared as an account of work sponsored by an agency of the United States Government. Neither the United States Government nor any agency Thereof, nor any of their employees, makes any warranty, express or implied, or assumes any legal liability or responsibility for the accuracy, completeness, or usefulness of any information, apparatus, product, or process disclosed, or represents that its use would not infringe privately owned rights. Reference herein to any specific commercial product, process, or service by trade name, trademark, manufacturer, or otherwise does not necessarily constitute or imply its endorsement, recommendation, or favoring by the United States Government or any agency thereof. The views and opinions of authors expressed herein do not necessarily state or reflect those of the United States Government or any agency thereof. 


\section{DISCLAIMER}

Portions of this document may be illegible in electronic image products. Images are produced from the best available original document. 
$$
\text { . }
$$ 


\section{CONTENTS}

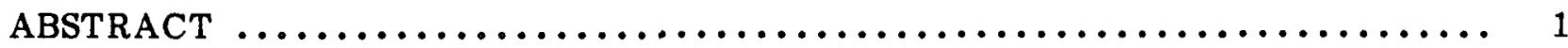

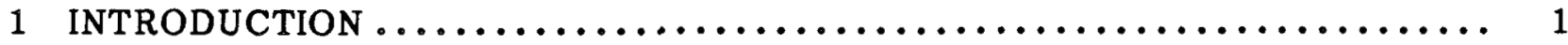

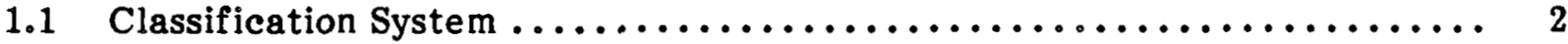

1.2 Identification of Highly Vulnerable Groundwaters $\ldots \ldots \ldots \ldots \ldots \ldots \ldots \ldots \ldots$

1.3 Application to Selected FUSRAP Sites $\ldots \ldots \ldots \ldots \ldots \ldots \ldots \ldots \ldots \ldots \ldots \ldots$

2 SITE-SPECIFIC EVALUATIONS $\ldots \ldots \ldots \ldots \ldots \ldots \ldots \ldots \ldots \ldots \ldots \ldots \ldots \ldots \ldots$

2.1 Wayne Interim Storage Site $\ldots \ldots \ldots \ldots \ldots \ldots \ldots \ldots \ldots \ldots \ldots \ldots \ldots \ldots \ldots \ldots$

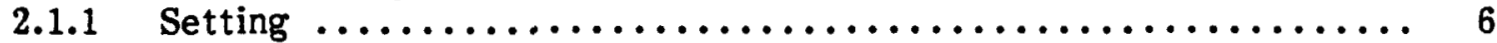

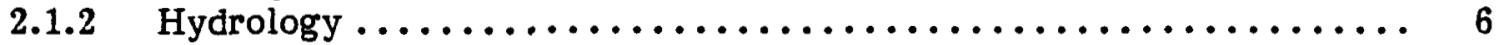

2.1.3 Federally Listed Species and Managed Lands ............... 9

2.2 Maywood Interim Storage Site $\ldots \ldots \ldots \ldots \ldots \ldots \ldots \ldots \ldots \ldots \ldots \ldots \ldots \ldots$

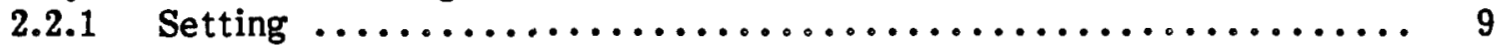

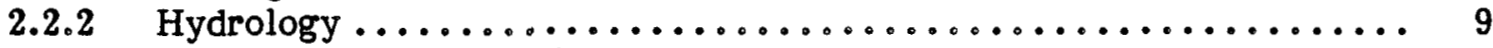

2.2.3 Federally Listed Species and Managed Lands ............... 11

2.3 Middlesex Sampling Plant $\ldots \ldots \ldots \ldots \ldots \ldots \ldots \ldots \ldots \ldots \ldots \ldots \ldots \ldots \ldots \ldots \ldots \ldots \ldots 11$

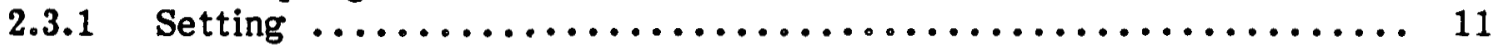

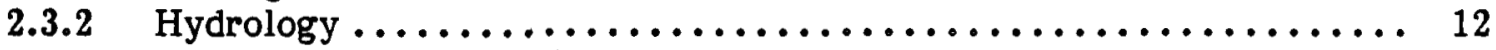

2.3.3 Federally Listed Species and Managed Lands ................ 14

2.4 Ashland 2 and Seaway Industrial Park Sites .................... 14

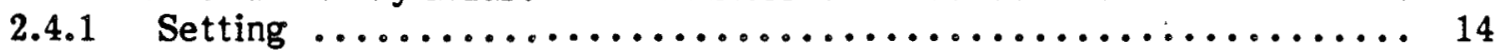

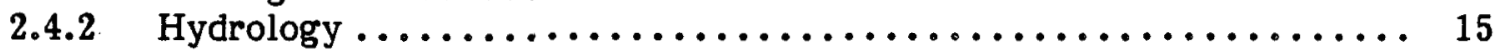

2.4.3 Federally Listed Species and Managed Lands .............. 18

2.5 Niagara Falls Storage Site $\ldots \ldots \ldots \ldots \ldots \ldots \ldots \ldots \ldots \ldots \ldots \ldots \ldots \ldots \ldots \ldots \ldots \ldots$

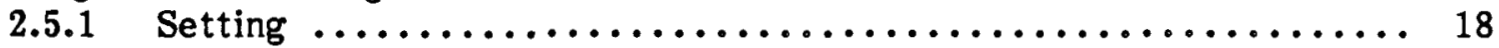

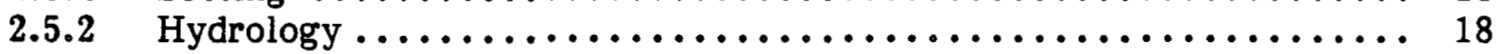

2.5.3 Federally Listed Species and Managed Lands .............. 22

2.6 Colonie Interim Storage Site $\ldots \ldots \ldots \ldots \ldots \ldots \ldots \ldots \ldots \ldots \ldots \ldots \ldots \ldots \ldots \ldots \ldots 22$

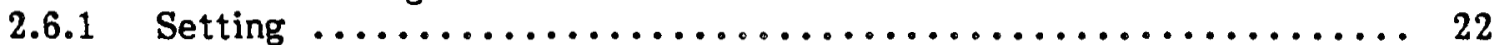

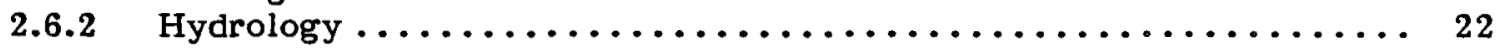

2.6.3 Federally Listed Species and Managed Lands .............. 25

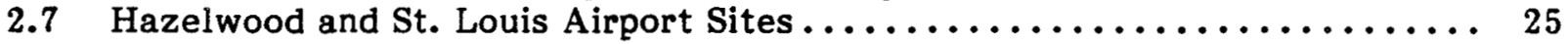

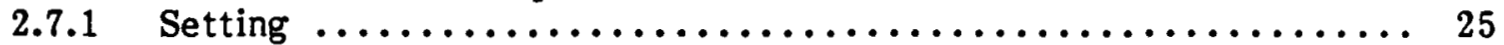

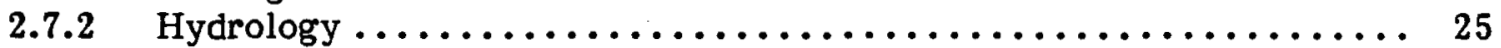

2.7.3 Federally Listed Species and Managed Lands .............. 29

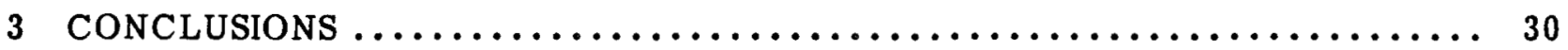

4 REFERENCES $\ldots \ldots \ldots \ldots \ldots \ldots \ldots \ldots \ldots \ldots \ldots \ldots \ldots \ldots \ldots \ldots \ldots \ldots \ldots \ldots \ldots \ldots \ldots \ldots$

APPENDIX: Letters of Consultation $\ldots \ldots \ldots \ldots \ldots \ldots \ldots \ldots \ldots \ldots \ldots \ldots \ldots \ldots \ldots$ 


\section{FIGURES}

1 Example of Class I Ecologically Vital Groundwater within

a Classification Review Area ........................... 3

2 Location of Wayne, New Jersey $\ldots \ldots \ldots \ldots \ldots \ldots \ldots \ldots \ldots \ldots \ldots \ldots \ldots \ldots$

3 Surface Drainage in the Vicinity of the Wayne Site $\ldots \ldots \ldots \ldots \ldots \ldots$

4 Location of Maywood, New Jersey .......................... 10

5 Surface Drainage in the Vicinity of the Maywood Site $\ldots \ldots \ldots \ldots \ldots \ldots \ldots$

6 Location of Middlesex, New Jersey $\ldots \ldots \ldots \ldots \ldots \ldots \ldots \ldots \ldots \ldots \ldots \ldots \ldots$

7 Surface Drainage in the Vicinity of the Middlesex Site .............. 15

8 Locations of the Ashland and Seaway Sites $\ldots \ldots \ldots \ldots \ldots \ldots \ldots \ldots$

9 Surface Drainage in the Vicinity of the Ashland and Seaway Sites $\ldots \ldots \ldots \ldots$

10 Location of Niagara Falls Storage Site $\ldots \ldots \ldots \ldots \ldots \ldots \ldots \ldots \ldots \ldots \ldots \ldots \ldots \ldots \ldots$

11 Natural Surface Drainage Patterns in the NFSS Area ................ 20

12 Current Drainage Features at NFSS and Surrounding Areas ............. 21

13 Location of Colonie, New York, Site $\ldots \ldots \ldots \ldots \ldots \ldots \ldots \ldots \ldots \ldots \ldots$

14 Surface Water Drainage in the Vicinity of the Colonie Site ............ 24

15 Locations of the SLAPS and Hazelwood Sites $\ldots \ldots \ldots \ldots \ldots \ldots \ldots \ldots \ldots \ldots \ldots$

16 Layout of the Hazelwood Site $\ldots \ldots \ldots \ldots \ldots \ldots \ldots \ldots \ldots \ldots \ldots \ldots \ldots \ldots \ldots$

17 Layout of SLAPS $\ldots \ldots \ldots \ldots \ldots \ldots \ldots \ldots \ldots \ldots \ldots \ldots \ldots \ldots \ldots \ldots \ldots \ldots$ 


\title{
DETERMINATION OF ECOLOGICALLY VITAL GROUNDWATERS AT SELECTED SITES IN THE FORMERLY UTILIZED SITES \\ REMEDIAL ACTION PROGRAM
}

\section{by}

William S. Vinikour and Stephen C.L. Yin

\begin{abstract}
The U.S. Department of Energy is classifying groundwaters at sites in its Formerly Utilized Sites Remedial Action Program (FUSRAP) based on the U.S. Environmental Protection Agency's Guidelines for Groundwater Classification under the EPA Groundwater Protection Strategy. Of particular concern is the potential presence of groundwaters that are highly vulnerable to contamination and that are either (1) irreplaceable sources of drinking water or (2) ecologically vital. Conditions at nine FUSRAP sites were evaluated to determine if ecologically vital groundwaters are present. (The presence of irreplaceable sources of drinking water was not considered in this analysis.) The sites evaluated were Wayne Interim Storage Site, Maywood Interim Storage Site, and Middlesex Sampling Plant in New Jersey; Ashland 2 Site, Seaway Industrial Park, Colonie Interim Storage Site, and Niagara Falls Storage Site in New York; and the St. Louis Airport Site and Hazelwood Interim Storage Site in Missouri. The analyses indicated that groundwaters are vulnerable to contamination at all but two of the sites - the Ashland 2 and Seaway Industrial Park sites in New York. Groundwater discharge points were identified within a 2-mi radius (i.e., the classification review area) of all of the sites. No critical habitats for any federally listed threatened or endangered species were identified within the classification review areas of the selected FUSRAP sites. Also, no federal lands managed for ecological protection were identified within these areas. Thus, it is concluded on the basis of these findings that no ecologically vital groundwater areas exist in the vicinities of any of the nine FUSRAP sites evaluated.
\end{abstract}

\section{INTRODUCTION}

In August 1984, the U.S. Environmental Protection Agency (EPA) announced a strategy to protect groundwater by establishing a three-tiered classification system based on the resource's value to society, its use, and its vulnerability to contamination (EPA 1986). The basic concept of the system is to classify the groundwater in an area of 
concern and then implement protective or remediation measures appropriate to that level of classification.

Environmental Protection Agency rule-making actions for Superfund and for radioactive-waste-disposal activities have incorporated aspects of the classification system. Thus, for activities such as those conducted under the Department of Energy's (DOE's) Formerly Utilized Sites Remedial Action Program (FUSRAP), the classification of groundwater resources is expected to become an additional step in site-specific analyses. The classification system will be implemented in conjunction with the sitespecific assessments normally conducted to comply with EPA permits and to select appropriate remedial actions. As discussed below, the EPA has issued draft guidelines to assist in the classification process (EPA 1986).

\subsection{CLASSIFICATION SYSTEM}

The EPA classification system provides for three general classes of groundwater:

- Class I -- special groundwater,

- Class II -- groundwater currently and potentially a source for drinking water, and

- Class III -- groundwater not a source of drinking water.

Class I groundwaters are resources of unusually high value that are highly vulnerable to contamination and are (1) irreplaceable sources of drinking water or (2) ecologically vital. The EPA's differential system designates Class I groundwaters as deserving a very high level of protection. A groundwater source is considered irreplaceable if it serves a substantial population and if reliable delivery of comparable quantity and quality of water from alternative sources would be economically infeasible or precluded by institutional constraints.

Ecologically vital groundwaters are those that supply a sensitive ecological system that supports a unique habitat. A sensitive ecological system is defined as an aquatic or terrestrial ecosystem located in an area of groundwater discharge. Such systems are generally associated with natural areas of groundwater discharge, such as seeps, springs, caves, wetlands, streams, bays, or playas. Unique habitats include (1) those used for federally listed or proposed endangered or threatened species, or (2) federal land management areas that are congressionally designated and managed for the purpose of ecological protection. This latter class includes national parks, national wilderness areas, national wildlife refuges, and national research natural areas (EPA 1986).

For inclusion in the EPA's classification system, groundwater discharge areas must be located within a specified distance (the classification review area) from the site of concern. Delineation of this area is necessary because EPA's strategy is to classify groundwater on a site-specific basis rather than on a regional or aquifer-specific basis. The classification review area is initially within a $3.2-\mathrm{km}(2-\mathrm{mi})$ radius from the boundaries of the site facility or activity (Fig. 1). Within this area, a preliminary 


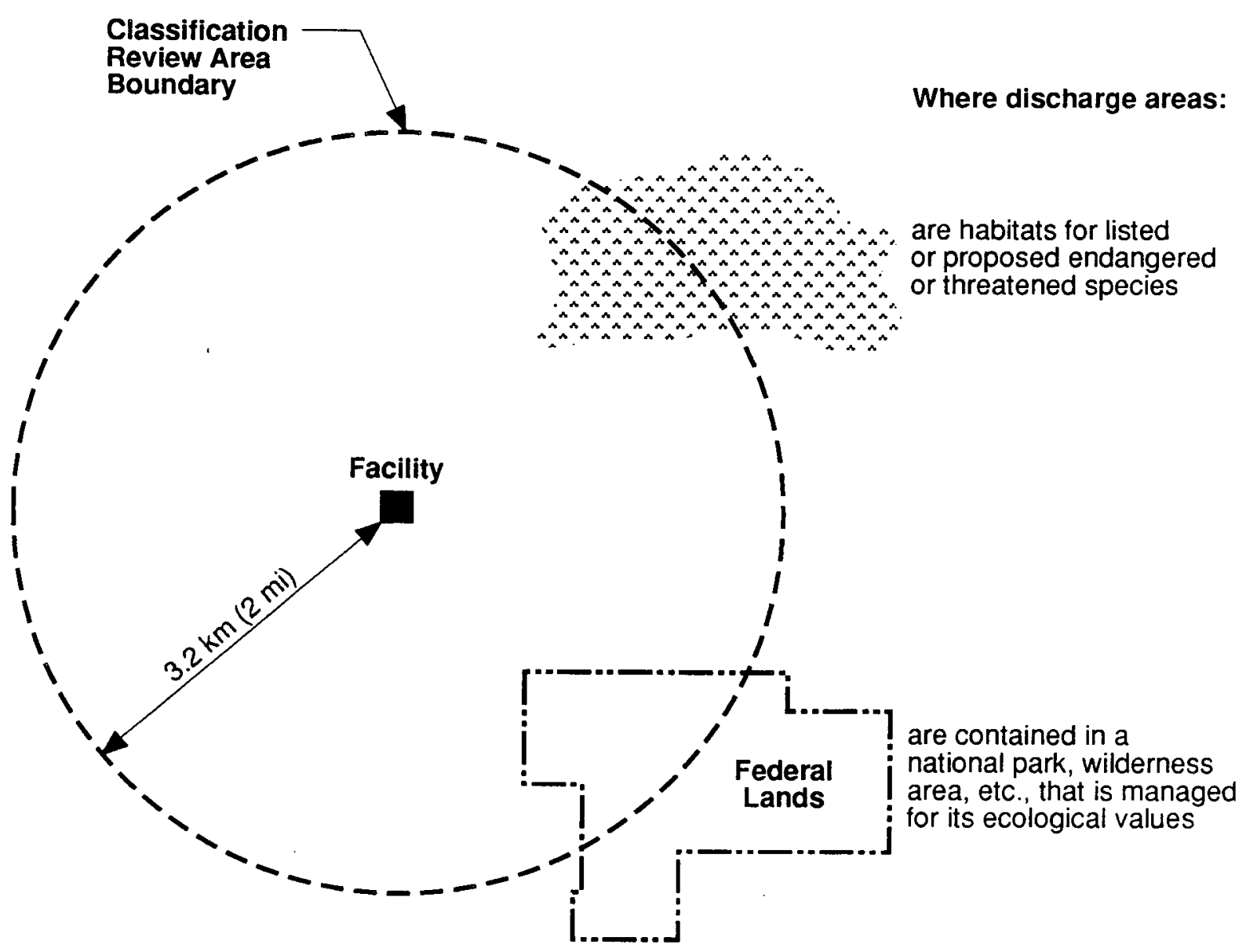

FIGURE 1 Example of Class I Ecologically Vital Groundwater within a Classification Review Area (Source: Adapted from EPA 1986)

inventory is made of public water-supply wells, populated areas not served by public supply, wetlands, and surface waters. If such features occur, then a determination is to be made as to whether they are highly vulnerable to contamination and, as relates to this report, ecologically vital. Figure 1 illustrates schematically the concept of the occurrence of an ecologically vital groundwaters in a classification review area.

\subsection{IDENTIFICATION OF HIGHLY VULNERABLE GROUNDWATERS}

Highly vulnerable groundwaters are characterized by a relatively high potential for contaminants to enter and, perhaps, to be transported by the flow system. The EPA guidelines for groundwater classification propose two methods (A and B) for defining vulnerability (EPA 1986). Method A uses the DRASTIC system (Aller et al. 1987), a numerical ranking system developed by the National Water Well Association for the 
EPA. The method is based on the examination of seven hydrogeologic characteristics of an area:

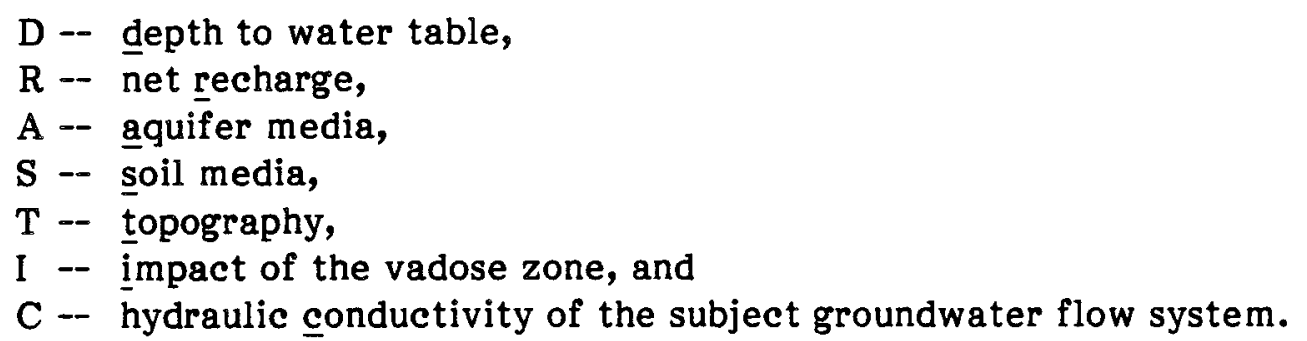

Determination of groundwater vulnerability would be based on the composite numerical value for the area being analyzed; the higher the score, the greater the vulnerability.

Method B proposed by the EPA allows users of the guidelines to examine the same seven criteria used in Method A or other sets of criteria to determine the vulnerability of the groundwater without using a numerical ranking system such as is used by the DRASTIC system.

To be classified as Class I, groundwater in an area must be not only highly vulnerable but also an irreplaceable source of drinking water or ecologically vital, or both.

\subsection{APPLICATION TO SELECTED FUSRAP SITES}

This report is intended to assist the DOE (Oak Ridge Operations Office) in classifying groundwaters at nine selected FUSRAP sites by identifying any ecologically vital groundwaters (EPA 1986) that occur at those locations. This report deals only with the identification, at the nine sites, of any Class I groundwaters that are both highly vulnerable to contamination and ecologically vital. Irreplaceable sources of drinking water are being identified separately by the DOE (Hovey 1988), and Class II and III groundwaters are outside the scope of this report.

The following assumptions and procedures were adopted to determine if ecologically vital groundwaters occur within the classification review area of the selected FUSRAP sites. First, 7.5-minute topographic maps encompassing a 3.2-km (2-mi) radius around each FUSRAP site were examined. When available, U.S. Fish and Wildlife Service wetland inventory maps also were examined. For initial screening, it was conservatively assumed that all surface waters (including wetlands) within the classification review area could be potential groundwater discharge points and could be hydrogeologically connected to the FUSRAP sites.

Concurrently with the above, the literature was reviewed to determine (1) if the ranges of federally listed (or proposed) threatened and endangered species could include the FUSRAP sites, and (2) which, if any; of these species are dependent (at least partially) upon habitats characteristic of groundwater discharge points. Additionally, letters of inquiry were sent to U.S. Fish and Wildlife Service endangered species field 
offices for a listing of threatened or endangered species that might occur within the immediate vicinity of the FUSRAP sites (see Appendix at the end of this document).

If the probability of the presence of listed species or their critical habitats within the classification review area was high, or if federally managed lands were present, further procedures were to be implemented. These procedures would include field surveys for the presence of listed species or habitats that could support them. Also, a more critical review of the hydrogeologic data would be undertaken (1) to more accurately assess groundwater interconnections between the FUSRAP site and habitat for the listed species and (2) to determine if the classification review area was a highly vulnerable hydrogeologic setting. As mentioned above, both the presence of ecologically vital areas and a highly vulnerable hydrogeologic setting are required for a rating of Class I - Ecologically Vital Groundwater. 


\section{SITE-SPECIFIC EVALUATIONS}

The nine FUSRAP sites where groundwater must be classified are the Wayne Interim Storage Site, Maywood Interim Storage Site, and Middlesex Sampling Plant in New Jersey; the Ashland 2 Site, Seaway Industrial Park, Niagara Falls Storage Site, and Colonie Interim Storage Site in New York; and the Hazelwood Site and St. Louis Airport Site in Missouri (Hovey 1988). The following sections briefly describe the setting of each site and present sufficient information on hydrological and environmental conditions to determine the presence of any ecologically vital and vulnerable groundwaters. More detailed information on site characteristics, contamination, and completed or planned remedial actions is provided in the documents referenced in the following site summaries and listed in Sec. 4.

\subsection{WAYNE INTERIM STORAGE SITE}

\subsubsection{Setting}

The Wayne Interim Storage Site is located in northeastern New Jersey in the western portion of Wayne Township, Passaic County. The site is $1.9 \mathrm{~km}(1.2 \mathrm{mi})$ east of Pompton Plains and $2.9 \mathrm{~km}(1.8 \mathrm{mi})$ north of the town of Wayne. Newark is $29 \mathrm{~km}(18 \mathrm{mi})$ to the southeast (Fig. 2). The storage site is near the intersection of Black Oak Ridge Road (N.J. Route 202) and Pompton Plains Cross Road in Wayne Township. Land within the immediate vicinity of the Wayne site is used for a combination of industrial, commercial, agricultural, and residential purposes. Future land use in the vicinity is expected to remain primarily residential (ANL 1984a).

\subsubsection{Hydrology}

Soils at the Wayne site consists mostly of well-drained, sandy loams. A drainage ditch that originates south of the site flows north onto the site. A second drainage ditch flowing from east of the property joins the first ditch. The combined ditch then curves and flows west from the Wayne site through a stormwater sewer under a parking lot. The ditch resumes at the outfall of the stormwater sewer $200 \mathrm{~m}(670 \mathrm{ft})$ to the west of the site. The ditch then flows southwest for about $100 \mathrm{~m}(330 \mathrm{ft})$ into Sheffield Brook. About $0.8 \mathrm{~km}(0.5 \mathrm{mi})$ west of the site the brook empties into the Pompton River, a tributary of the Passaic River (Fig. 3) (ANL 1984a). Wetlands occur along Sheffield Brook. Before off-site remedial actions were conducted along the brook, three wetland types occurred: palustrine forested wetland, palustrine emergent wetland, and palustrine forested/scrub-shrub wetland (Kulp 1986). Currently, the wetland areas are in early secondary successional stages following remedial actions and consist primarily of palustrine emergent or emergent/scrub-shrub wetlands.

The site is underlain by two distinet geologic units: Quaternary unconsolidated glacial till and the Brunswick formation (Triassic sandstone). The unconsolidated 


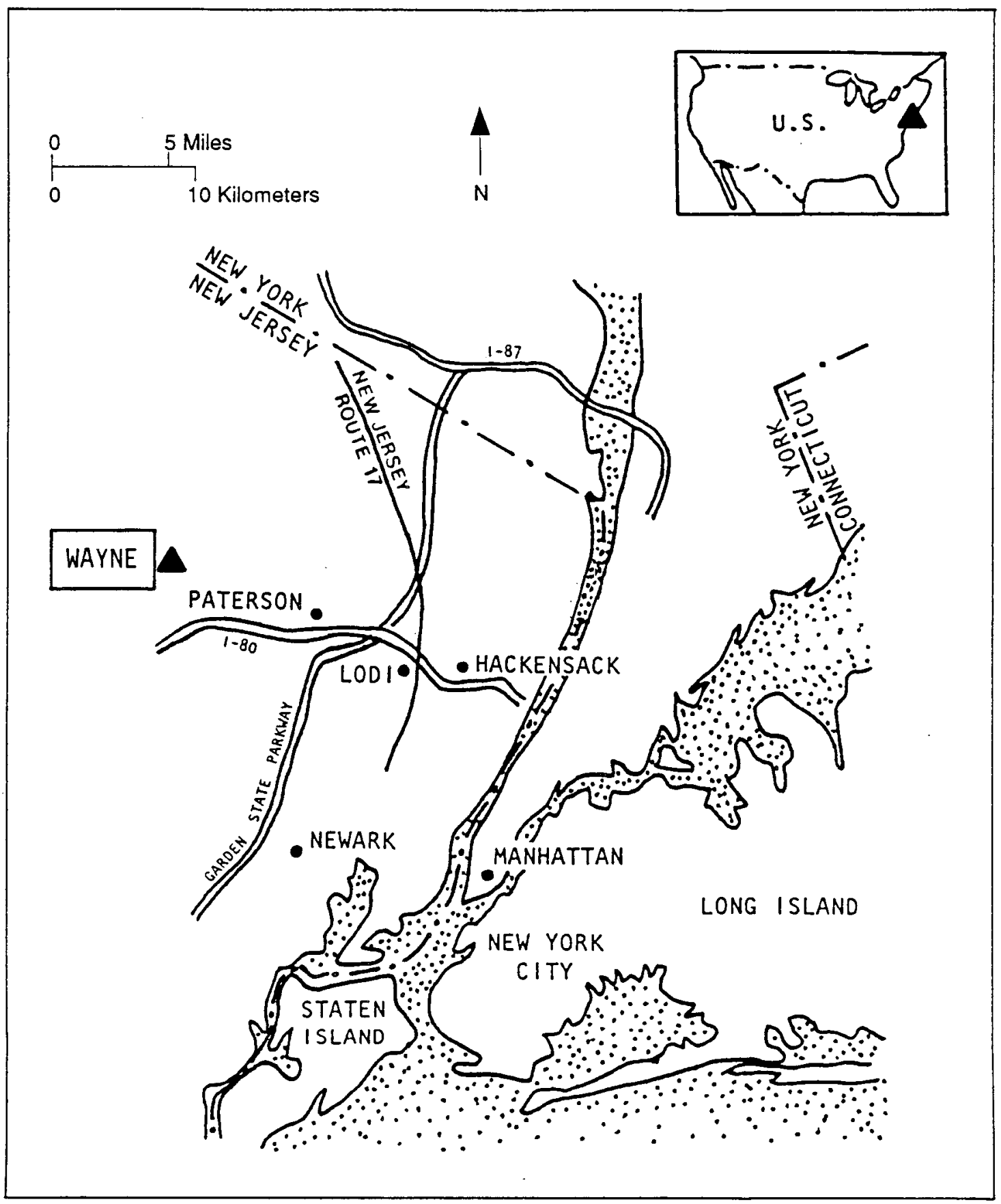

FIGURE 2 Location of Wayne, New Jersey (Source: Adapted from ANL 1984a) 


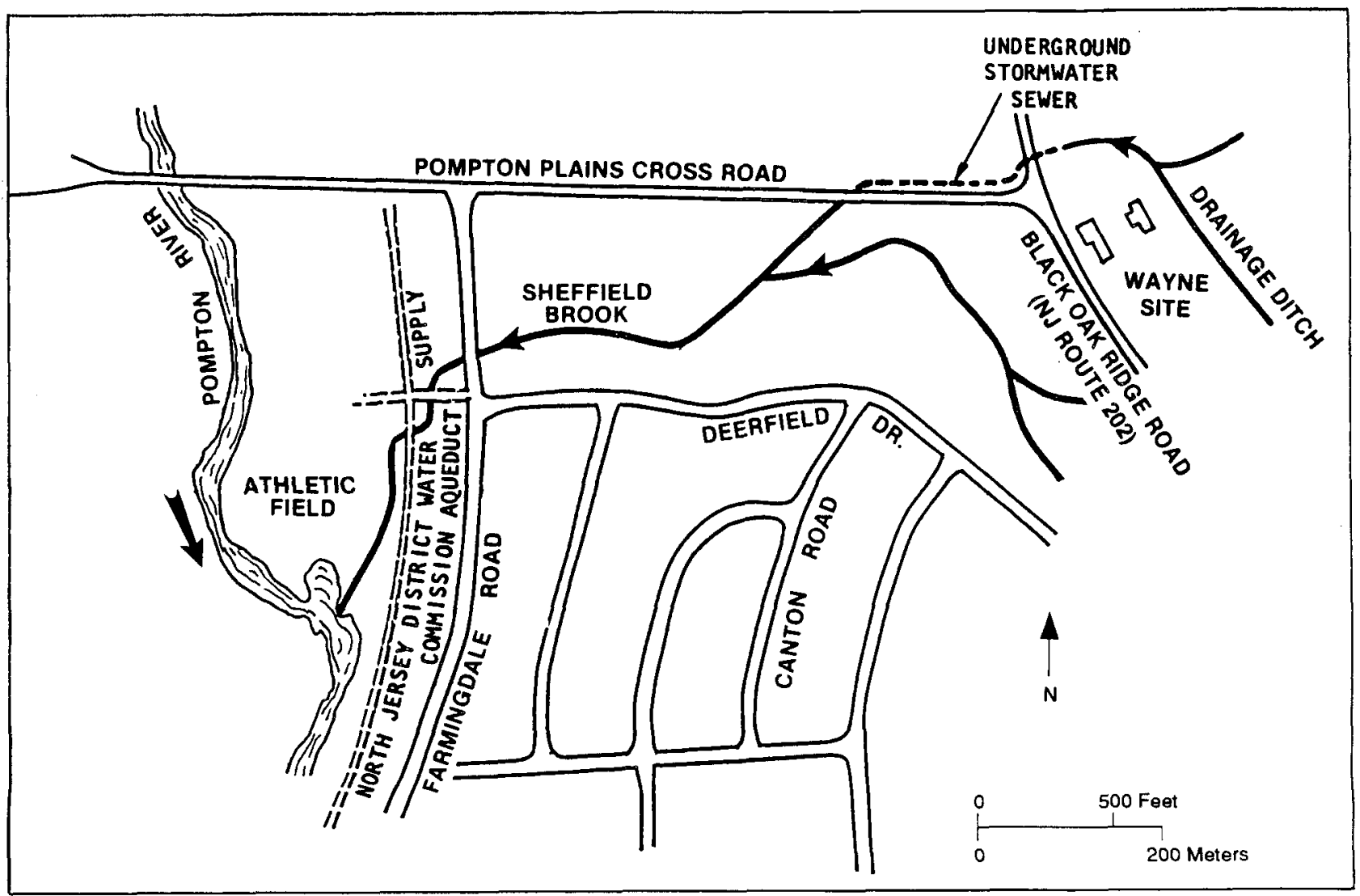

FIGURE 3 Surface Drainage in the Vicinity of the Wayne Site (Source: Adapted from ANL 1987a)

deposits are 6.4-13 $\mathrm{m}$ (21-41 ft) thick. The underlying Brunswick formation forms the bedrock in the area. The uppermost 4.6-6.1 m (15-20 ft) of the Brunswick formation contains numerous vertical to near-vertical, fresh to slightly weathered, open fractures (Bechtel 1986a).

In the site vicinity, groundwater occurs in both the unconsolidated deposits and in the Brunswick formation. Groundwater in the deposits probably flows to the southwest. Measurements from on-site wells, however, indicate a highly variable groundwater surface. This may be due to the nature of the deposits as well as to disturbance caused by the presence of waste burial areas on the site (ANL 1987a). In the vicinity of the Wayne site, groundwater in the bedrock aquifer flows to the west (Bechtel 1986a).

Although the unconsolidated deposits in the site vicinity have not been extensively explored and developed, they are an important source of water for public supply and industrial use in Wanaque, Pompton Lakes, and along the western side of Wayne Township. These areas are about 6,3 , and $6 \mathrm{~km}(4,2$, and $4 \mathrm{mi})$, respectively, from the site. Currently, the Brunswick formation is the major source of groundwater for public supply and industrial use in Passaic County (ANL 1987a). 
The groundwater in both the unconsolidated deposits and the bedrock at the Wayne site is considered vulnerable to contamination because of the (1) relatively permeable nature of the soils, unconsolidated deposits, and the bedrock, (2) shallow depth to the water table, and (3) relatively thin overburden above the bedrock formation.

\subsubsection{Federally Listed Species and Managed Lands}

Three federally endangered species and two threatened species may occur in the vicinity of the Wayne site. The endangered species are the bald eagle (Haliaeetus leucocephalus), American peregrine falcon (Falco peregrinus anatum), and roseate tern (Sterna dougallii dougallii). The two threatened species are the Arctic peregrine falcon (F. p. tundrius) and piping plover (Charadrius melodus). However, these species would be expected to occur over the area only as occasional transients (Chezik 1989).

The bald eagle breeds in forests, open areas, or mountains (usually in association with large bodies of water). It winters along the coast or inland near ice-free waters. Large bodies of water, pilot and perch trees, and isolation from human disturbance are important habitat requirements (DeGraaf and Rudis 1986; Forest Service 1977).

Breeding habitat for the peregrine falcon typically consists of high, rocky cliffs of mountains, which are of ten associated with water bodies. Wintering habitat consists mainly of barrier beaches or, more rarely, tall buildings in cities (DeGraaf and Rudis 1986). The piping plover requires undisturbed coastal sand beaches for breeding. Similar habitat, plus offshore islands, are used by the roseate tern (Dowhan and Craig 1976). Neither the piping plover nor the roseate tern winters in the north. No habitats critical for the survival of these species occur in the vicinity of the Wayne site. Thus, no impacts to these species would be anticipated from wastes currently contained at the site or from any further remedial actions that may be taken at the site.

No federal lands managed for ecological protection occur within a $3.2-\mathrm{km}$ (2-mi) radius of the Wayne Interim Storage Site.

\subsection{MAYWOOD INTERIM STORAGE SITE}

\subsubsection{Setting}

The Maywood Interim Storage Site is located in northeastern New Jersey about $21 \mathrm{~km}(13 \mathrm{mi})$ northeast of Newark. The site is in the borough of Maywood and the township of Rochelle Park, Bergen County, New Jersey (Fig. 4). Most of the land within a few kilometers of the site is zoned for residential or light-industrial use (ANL 1987b).

\subsubsection{Hydrology}

Terrain at the Maywood site is generally flat, with intermittent shallow ditches and slight mounds. The surface of the site slopes gently to the west and is poorly 


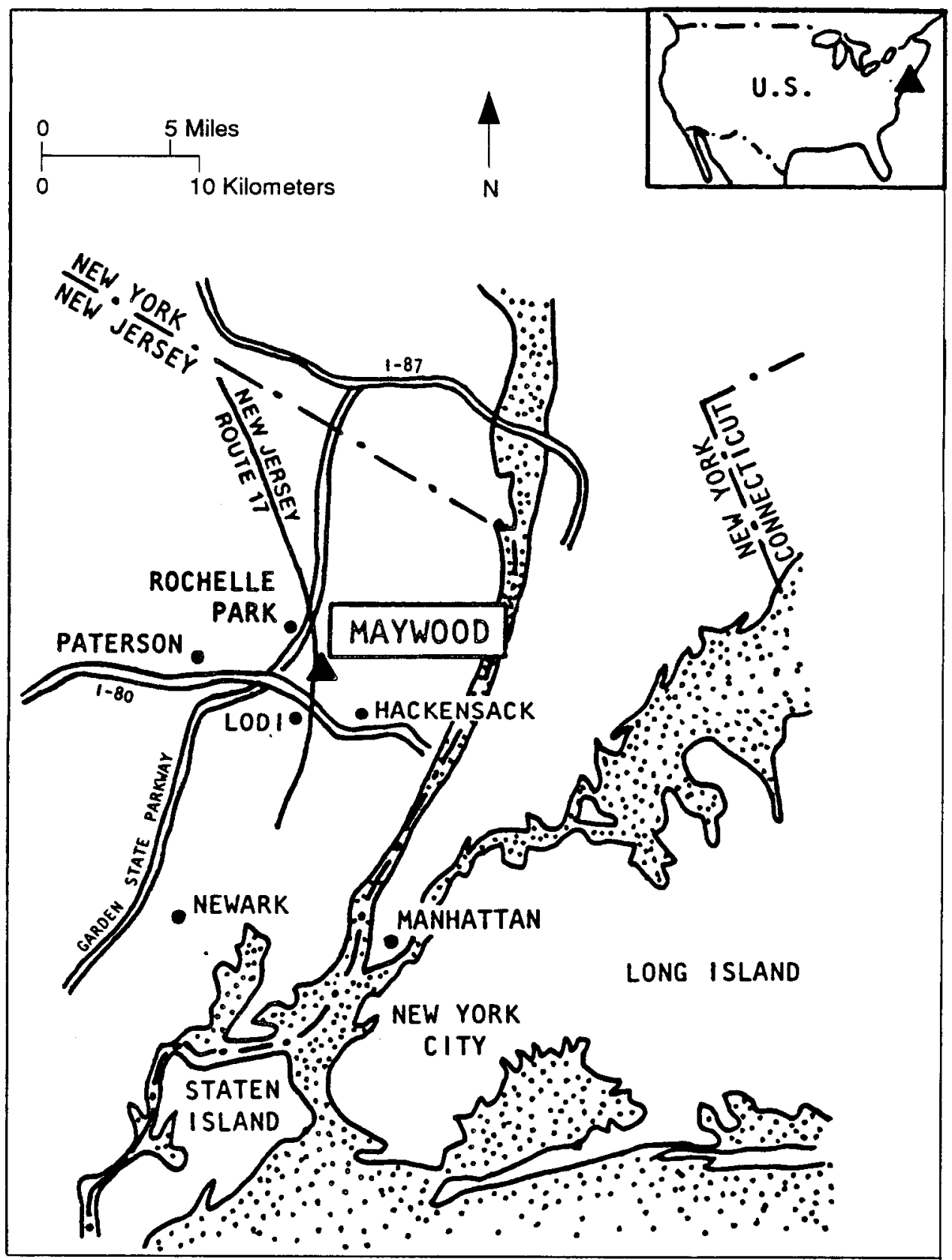

FIGURE 4 Location of Maywood, New Jersey (Source: Adapted from ANL 1987b) 
drained. Runoff from the site currently flows into the Saddle River via Westerley Brook (Fig. 5). The brook flows under the site through a concrete storm drain, passes under New Jersey Route 17, and eventually empties into the Saddle River. Neither Westerley Brook nor the Saddle River is used as a source of drinking water (ANL 1987b).

The bedrock underlying the area is the Brunswick formation (Bechtel 1985a). The formation is $1,800-2,400 \mathrm{~m}(6,000-8,000 \mathrm{ft})$ thick and is overlain by unconsolidated sand, gravel, silt, and clay deposits (primarily of glacial origin). These unconsolidated glacial materials are $0.55-6.6 \mathrm{~m}(1.8-22 \mathrm{ft}$ ) thick and consist primarily of stratified drift (ANL 1987b).

Most of the groundwater used in the area comes from the Brunswick formation (Bechtel 1985a). The uppermost 4.6-6.1 $\mathrm{m}$ (15-20 ft) of the formation of ten contains numerous vertical to nearly vertical, fresh to slightly weathered, open fractures. Storage and movement of groundwater within the formation is confined primarily to these openings (Bechtel 1985a). Some groundwater is available from the unconsolidated deposits; however, because of the nature of the deposits, well yields are highly variable (ANL 1987b).

The groundwater table at the Maywood site is generally shallow -- 2-3 $\mathrm{m} \mathrm{(7-10} \mathrm{ft)}$ below the ground surface. Measurements of groundwater levels indicate that the groundwater gradient in the area is slight (Bechtel 1985a). Flow both in the unconsolidated deposits and the bedrock generally is to the southwest.

The groundwater at the Maywood site both in the unconsolidated deposits and the bedrock is considered vulnerable to contamination because of the (1) relatively permeable nature of the soils, unconsolidated deposits, and the bedrock; (2) shallow depth to the water table; and (3) relatively thin overburden above the bedrock formation.

\subsubsection{Federally Listed Species and Managed Lands}

The bald eagle, peregrine falcon, piping plover, and roseate tern may occur in the vicinity of the Maywood site, but only as occasional transients (Chezik 1989). No habitats critical for the survival of these federally listed species occur in the vicinity of the Maywood site (see Sec. 2.1.3). Thus, no impacts to these species would be anticipated from wastes currently contained at the site or from any further remedial actions that may be taken at the site. No federal lands managed for ecological protection occur within a 3.2-km (2-mi) radius of the Maywood site.

\subsection{MIDDLESEX SAMPLING PLANT}

\subsubsection{Setting}

The Middlesex Sampling Plant is located in the urban area of Middlesex, New Jersey, about $29 \mathrm{~km}(18 \mathrm{mi})$ southwest of Newark (Fig. 6). A combination of residential, 


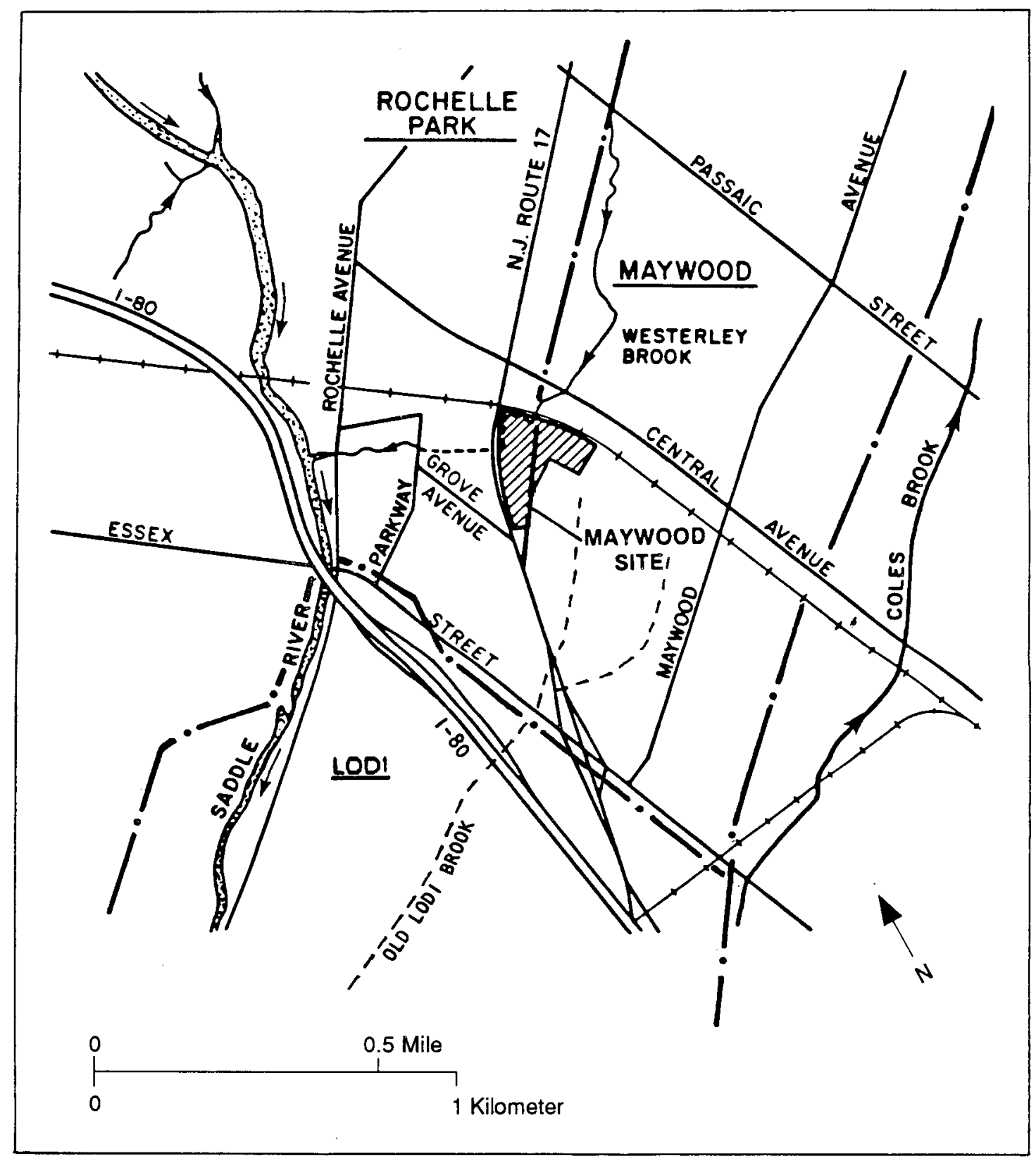

FIGURE 5 Surface Drainage in the Vicinity of the Maywood Site (Source: Adapted from ANL 1987b)

commercial, industrial, public, and vacant land occurs in the site vicinity. Future development is expected to be primarily residential and industrial (ANL 1984b).

\subsubsection{Hydrology}

The site of the Middlesex Sampling Plant is generally flat, ranging in elevation from $15 \mathrm{~m}(50 \mathrm{ft})$ mean sea level (MSL) on the southern boundary to $18 \mathrm{~m}(60 \mathrm{ft}) \mathrm{MSL}$ on the northern boundary. Soils at the site are silty to sandy loams ranging from 0.45 to 


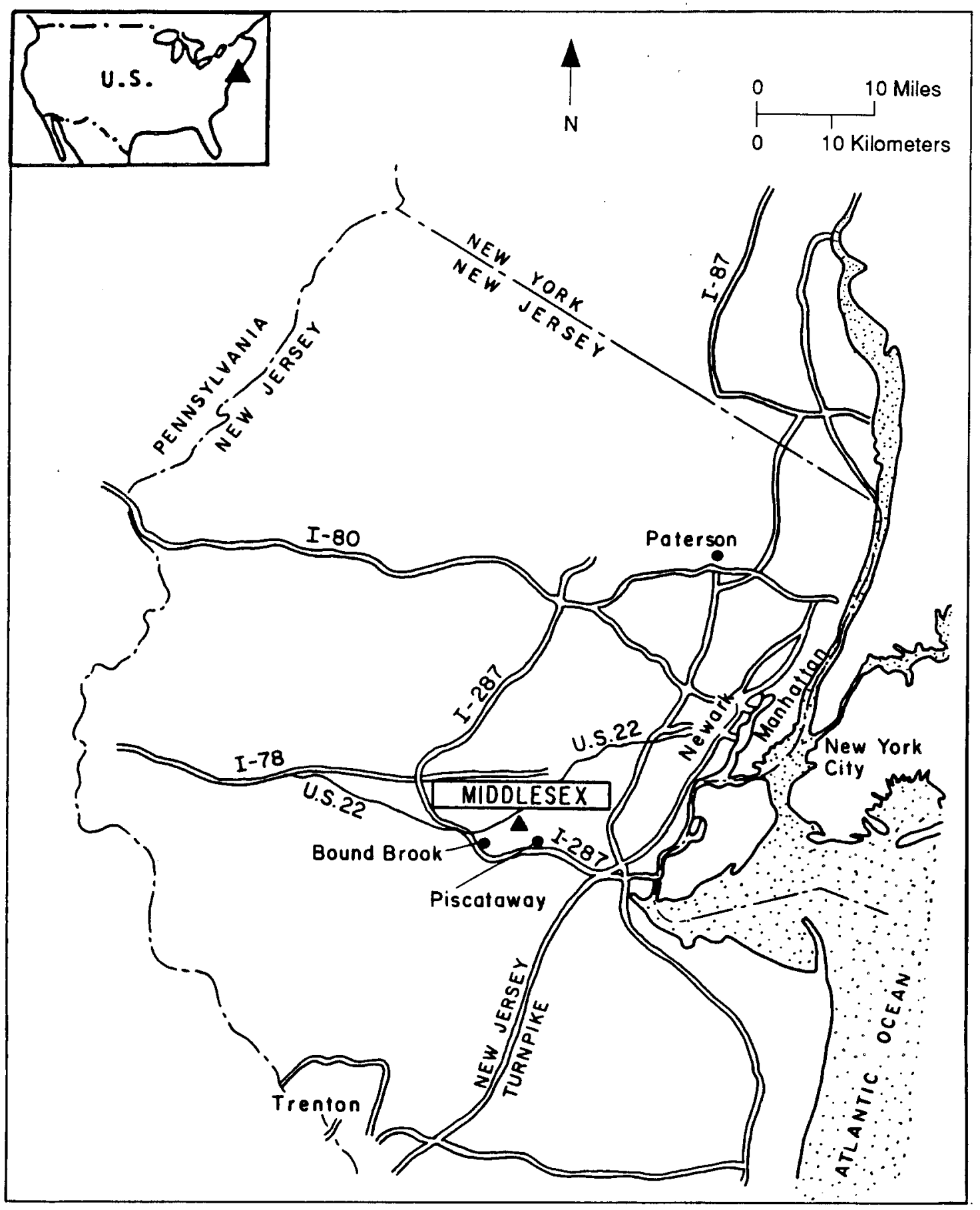

FIGURE 6 Location of Middlesex, New Jersey (Source: Adapted from ANL 1984b) 
$2.4 \mathrm{~m} \mathrm{(1.5} \mathrm{to} 8.0 \mathrm{ft}$ ) thick over bedrock. Surface runoff from the Middlesex site is collected in several drains that empty into a large settling basin through an underground drainage system. The settling basin empties into a drainage ditch south of the site. The ditch flows $180 \mathrm{~m}(600 \mathrm{ft})$ south to Main Stream. Main Stream empties into Ambrose Brook, which in turn flows into Green Brook near its confluence with the Raritan River (Fig. 7). Neither Main Stream or Ambrose Brook is used as a source of drinking water (ANL 1984b).

The bedrock underlying the site consists of shales of the Brunswick formation. Groundwater is available from shallow and deep systems under the site. The shallow unconfined aquifer is a zone located $0.6-3.0 \mathrm{~m}(2-10 \mathrm{ft})$ below the ground surface. Groundwater in this zone flows generally from north to south. The deep groundwater system is in the Brunswick shale, with flow from south to northeast. The fact that the deep and shallow systems flow in opposite directions indicates that a confining layer exists between the two aquifer systems (Bechtel 1989). The Brunswick formation is a major aquifer in the western part of Middlesex County and adjoining Essex County.

The shallow aquifer at the Middlesex site is considered vulnerable to contamination because of the shallow depth to the water table. Because of the possible existence of a confining layer (discussed above), the deep aquifer may not be as vulnerable. However, no detailed information on the confining layer is available.

\subsubsection{Federally Listed Species and Managed Lands}

The bald eagle, peregrine falcon, piping plover, and roseate tern may occur at the Middlesex site as occasional transients (Chezik 1989); however, no habitats critical for the survival of these species occur in the vicinity of the site (see Sec. 2.1.3). Thus, no impacts to these species would be anticipated from wastes currently contained at the site or from any additional remedial actions that may be taken at the site. No federal lands managed for ecological protection occur within a $3.2-\mathrm{km}(2-\mathrm{mi})$ radius of the Middlesex site.

\subsection{ASHLAND 2 AND SEAWAY INDUSTRIAL PARK SITES}

\subsubsection{Setting}

Ashland 2 and Seaway Industrial Park are adjacent sites in an industrialized area of Tonawanda, Erie County, New York. The area is about $4.8 \mathrm{~km} \mathrm{(3} \mathrm{mi)} \mathrm{northwest} \mathrm{of}$ Buffalo (Fig. 8). The Ashland 2 site consists generally of brushland transected by substantial marshy areas. The Seaway Industrial Park is an active landfill except for portions where low-level radioactive wastes have been buried. These portions are grown over with vegetation (grasses, brush, and small trees). 


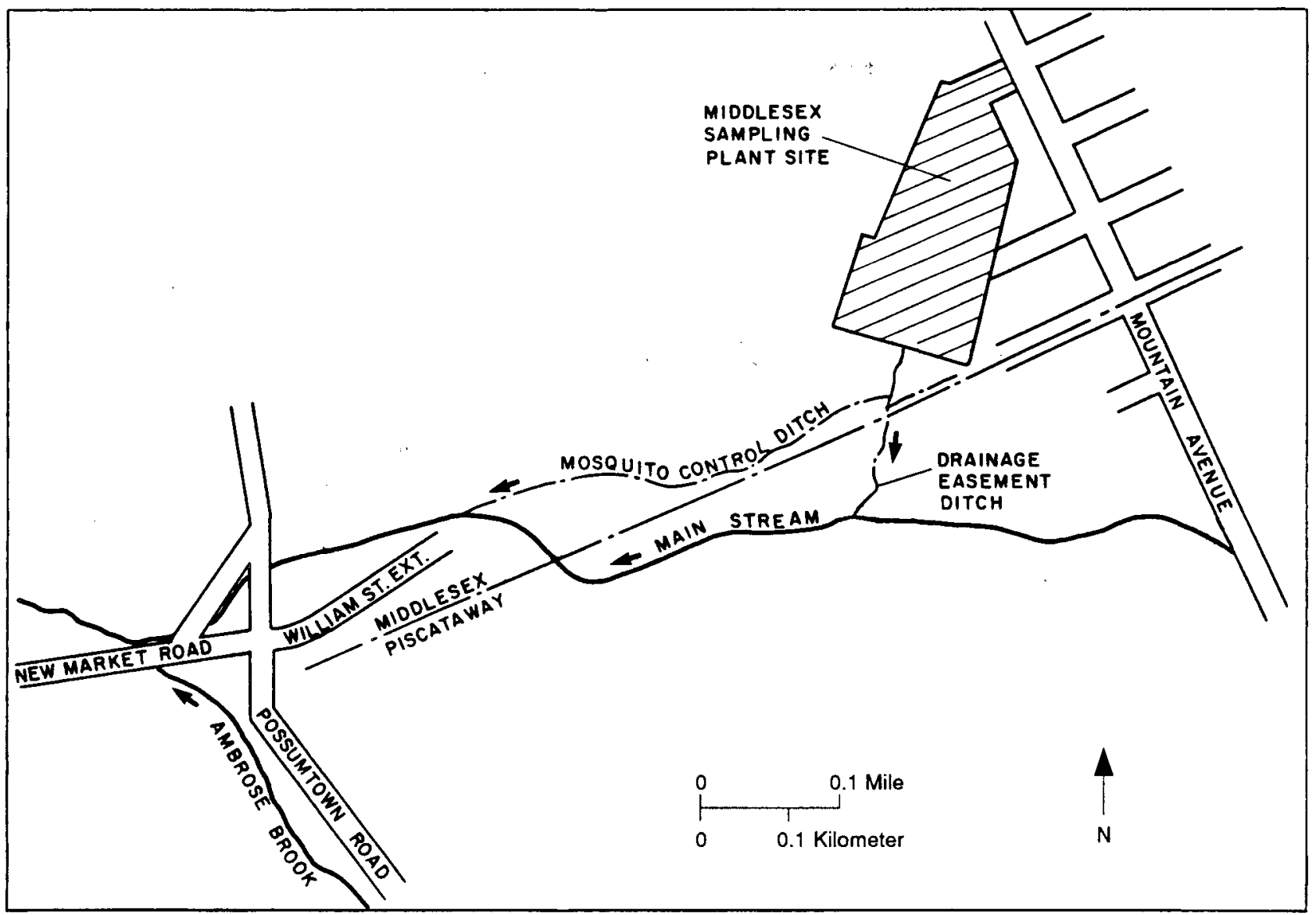

FIGURE 7 Surface Drainage in the Vicinity of the Middlesex Site (Source: Adapted from ANL 1984b)

\subsubsection{Hydrology}

Runoff from the Ashland 2 and Seaway Industrial Park sites enters a number of drainage channels that cross the sites from the southeast. These various channels combine into one channel northeast of the Ashland 2 site. The combined drainage channel flows north into Twomile Creek about $1.6 \mathrm{~km}(1 \mathrm{mi})$ northeast of the Ashland 2 site (Fig. 9). In turn, the creek flows into the Niagara River.

The main aquifer in the vicinity of the Ashland/Seaway sites is in the Camillus shale bedrock of Silurian age. The aquifer has a potential for high groundwater yields, but the dissolved solids content appears to be too high for most uses. A relatively permeable glaciolacustrine unit and a sandy glacial till overlying the Camillus shale are hydraulically connected with the shale and are included in the following discussion. Overlying the glaciolacustrine unit and the sandy glacial till is a low-permeability glacial clay unit averaging about $18 \mathrm{~m}(60 \mathrm{ft})$ thick. Soils and the landfill overlie the glacial clay unit. 


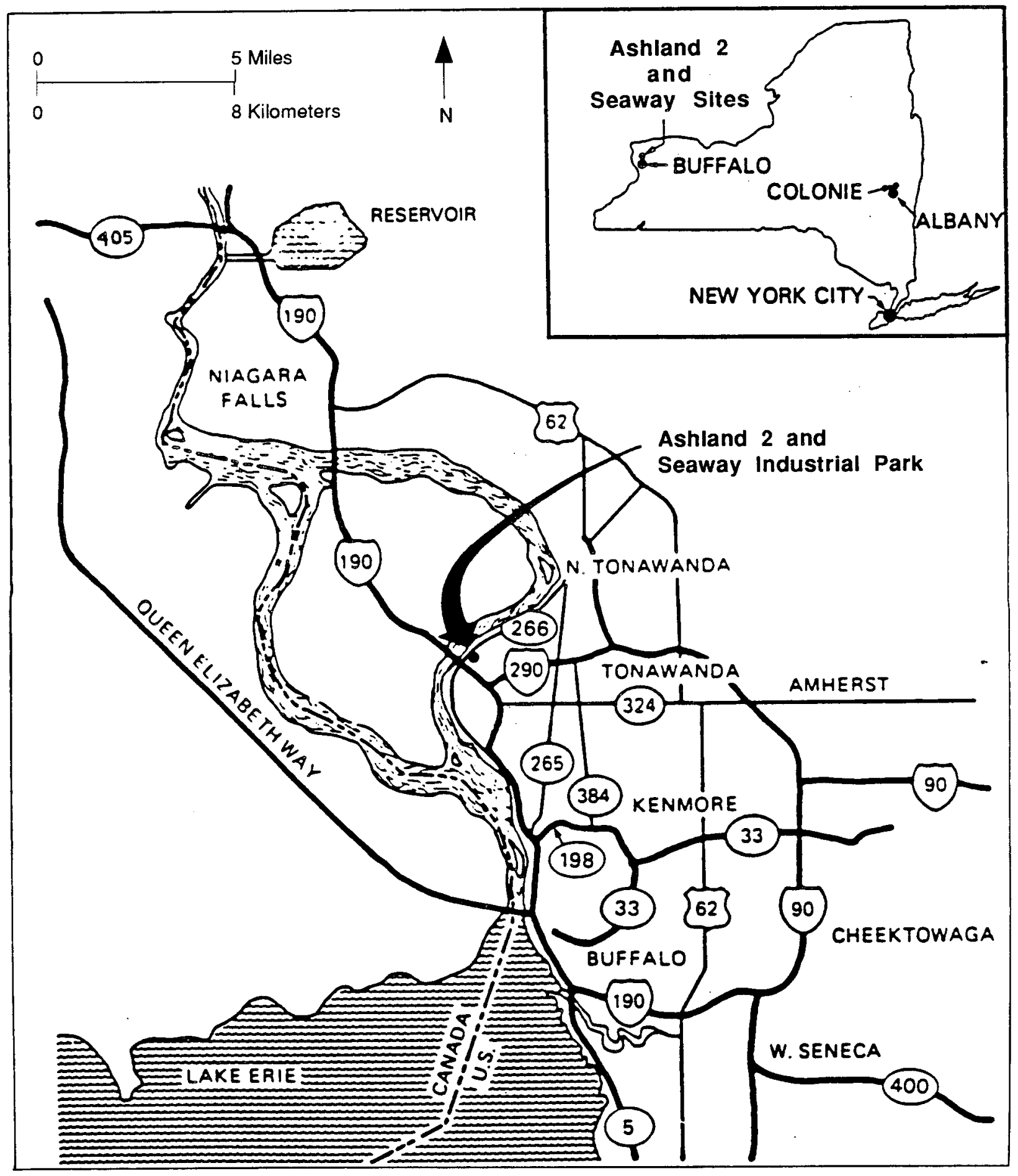

FIGURE 8 Locations of the Ashland and Seaway Sites (Source: Adapted from Bechtel 1988) 


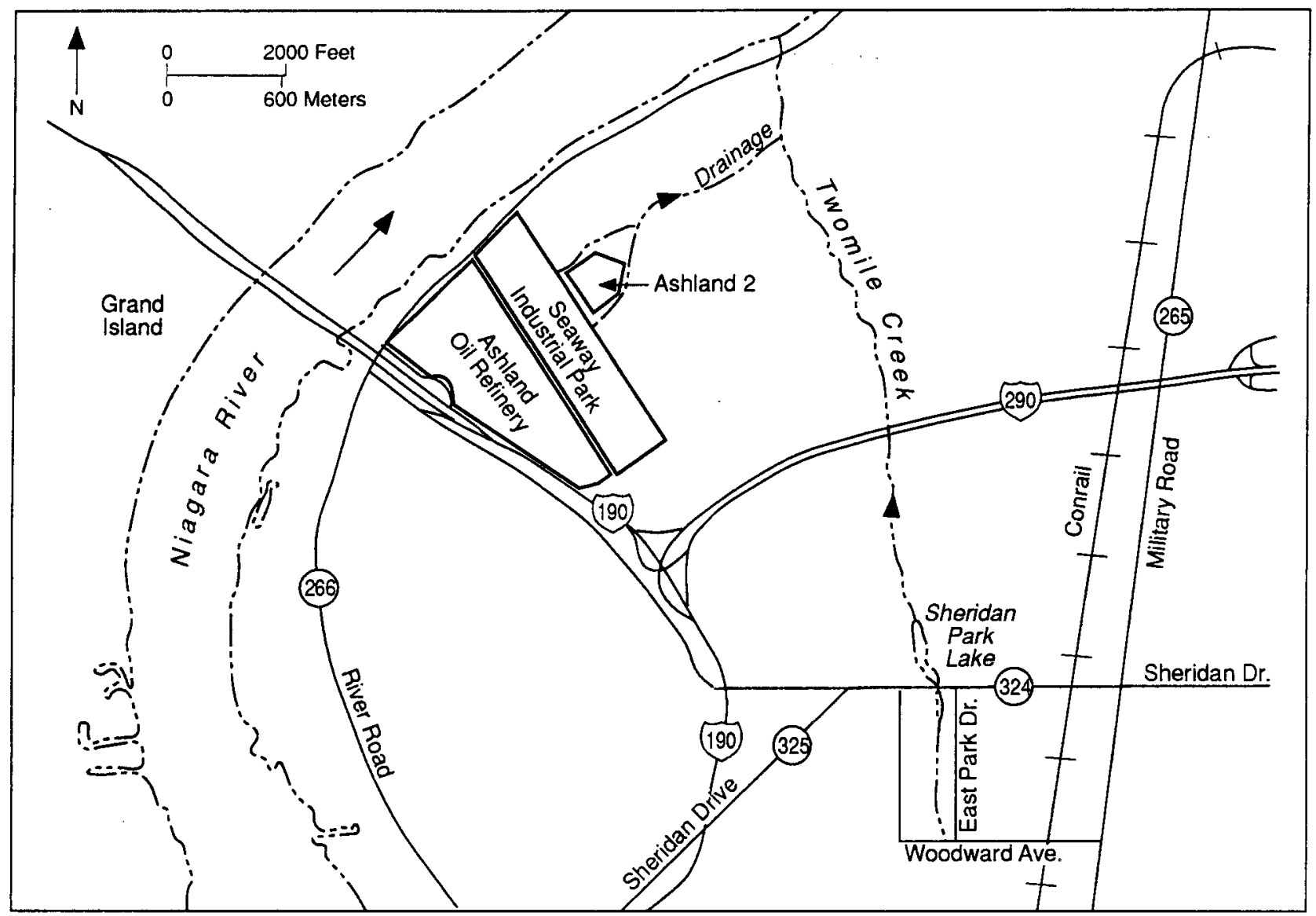

FIGURE 9 Surface Drainage in the Vicinity of the Ashland and Seaway Sites (Source: Adapted from Bechtel 1988)

At the Seaway Industrial Park, a groundwater mound has formed within virtually all portions of the landfill. The water table is contained within the solid waste, which forms the topographic surface of much of the Seaway site. The water table has a variable surface subject to seasonal fluctuations in response to varying rates of recharge from precipitation. The base of this water-bearing zone corresponds to the top of the nearly impervious glacial clay unit (Wehran and RECRA 1979).

The groundwater in the Camillus shale aquifer occurs in the numerous joints and bedding planes. The Camillus shale is the most productive aquifer in the area, although the water quality is poor. Bedrock groundwater in the site vicinity generally flows west toward the Niagara River. The glaciolacustrine unit and the sandy glacial till overlying the Camillus shale both exhibit some water-bearing capacity, although they are much less permeable than the shale.

The downward migration of leachate from the Seaway landfill through the underlying glacial clay unit into the glaciolacustrine unit, the sandy glacial till, and the Camillus shale aquifer is essentially precluded by the extremely low permeability of the glacial clay. The clay unit varies between 14 and $23 \mathrm{~m}$ (45 and $75 \mathrm{ft}$ ) thick, averaging 
about $18 \mathrm{~m}(60 \mathrm{ft})$. The permeability of clay unit has been estimated as $1.6 \times 10^{-8} \mathrm{~cm} / \mathrm{s}$ $\left(6.3 \times 10^{-9}\right.$ in./s) (Wehran and RECRA 1979).

A compacted clay cutoff wall keyed into the upper clays of the underlying glacial till was installed around the landfill site in 1983. A perimeter leachate collection system was installed inside the cutoff wall to control mounding groundwater and to monitor leachate. The leachate exits the Seaway landfill through numerous seeps, or springs, along the toe of slope of the landfill and discharges into the surface streams. Therefore, the primary potential impact of the leachate on the area's water resources would be pollution of surface streams emanating from or passing through the landfill.

The Camillus shale aquifer is considered to have low vulnerability to contamination by the radioactive waste at the site because the aquifer is separated from the waste by the relatively thick, impermeable glacial clay.

\subsubsection{Federally Listed Species and Managed Lands}

The only federally listed species that may occur in the vicinity of the Ashland 2 and Seaway Industrial Park sites are the bald eagle and peregrine falcon. However, these species would be expected to occur over the area only as occasional transients (Gill 1989). No habitats critical for the survival of these species occur in the vicinity of the sites (see Sec. 2.1.3). Thus, no impacts to either species would be anticipated from wastes currently contained at the sites or from any further remedial actions that may be taken at the sites. No federal lands managed for ecological protection occur within a $3.2-\mathrm{km}(2-\mathrm{mi})$ radius of the Ashland 2 or Seaway Industrial Park sites.

\subsection{NIAGARA FALLS STORAGE SITE}

\subsubsection{Setting}

The Niagara Falls Storage Site (NFSS) is located in Lewiston, Niagara County, New York (Fig. 10). The site is $30 \mathrm{~km}(19 \mathrm{mi})$ north of Buffalo. Land use in the immediate vicinity of the site includes a hazardous waste disposal site, a sanitary landfill, federally owned land used for training operators of construction equipment, a power line corridor, and privately owned land. Homes, a trailer park, schools, and campgrounds are located less than $3 \mathrm{~km}(2 \mathrm{mi})$ from the site. Lewiston and Porter are generally rural and land use types include active agricultural areas, old fields, recreational areas, and second-growth forests (DOE 1986).

\subsubsection{Hydrology}

Natural drainages in the area of NFSS are shown in Fig. 11. Historically, Fourmile, Sixmile, and Twelvemile creeks all received runoff from the site. However, in the 1940s, a series of ditches were dug, and Sixmile Creek was diverted to alter the 


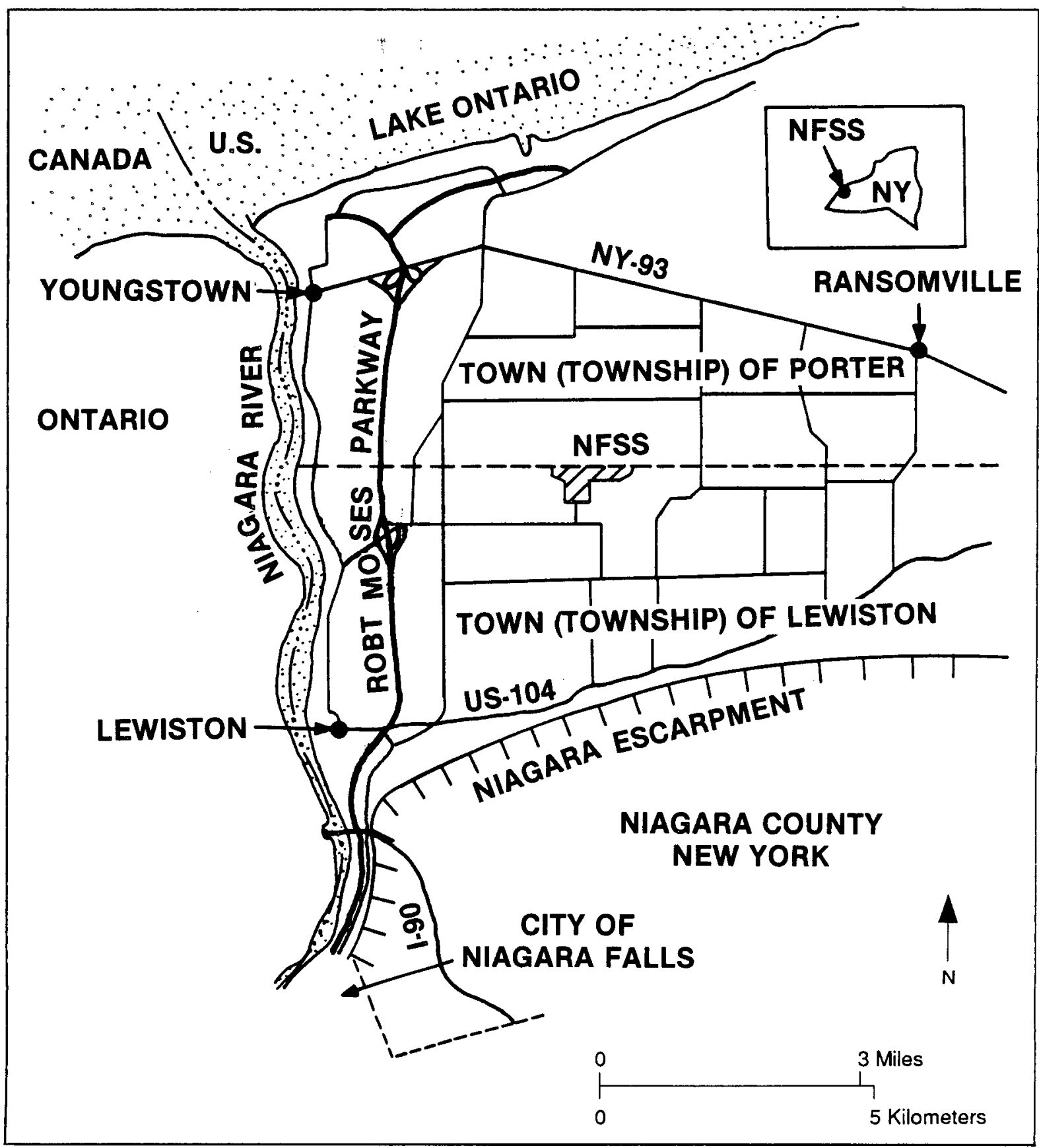

FIGURE 10 Location of Niagara Falls Storage Site (NFSS) (Source: Adapted from DOE 1986) 


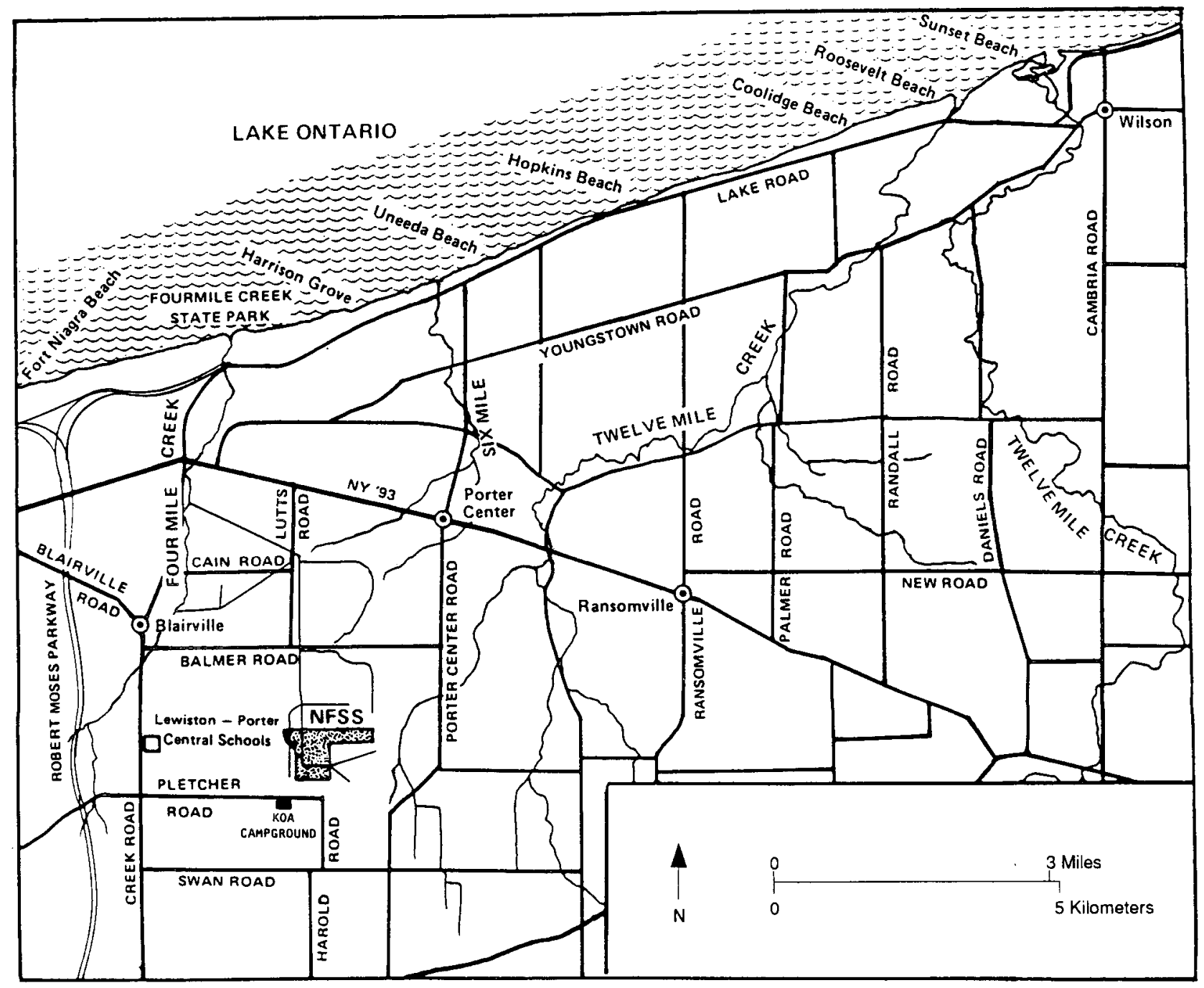

FIGURE 11 Natural Surface Drainage Patterns in the NFSS Area (Source: Adapted from DOE 1986)

drainage pattern of the area. Since then, drainage from the site flows primarily into Fourmile Creek (Fig. 12), which in turn flows into Lake Ontario (DOE 1986).

Within Niagara County, groundwater is present both in the surficial glacial deposits and the underlying bedrock. The three most significant water-bearing zones at

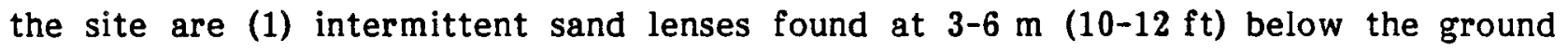
surface (upper soil aquifer), (2) a brown, gravelly, sand-silt layer found at 9-12 m $(30-40 \mathrm{ft}$ ) below ground surface (lower soil aquifer), and (3) the weathered and fractured 3- to 4.5-m (9.9- to 15- $\mathrm{ft}$ ) thick upper surface of the Queenston formation, beginning about $15 \mathrm{~m}(50 \mathrm{ft}$ ) below the ground surface (bedrock aquifer). The lower soil aquifer flows northwest and discharges into Lake Ontario, the Niagara River, and local streams and ditches. The major zone of groundwater movement is in the weathered and fractured bedrock aquifer in the upper portion of the Queenston formation. Where the red till is 


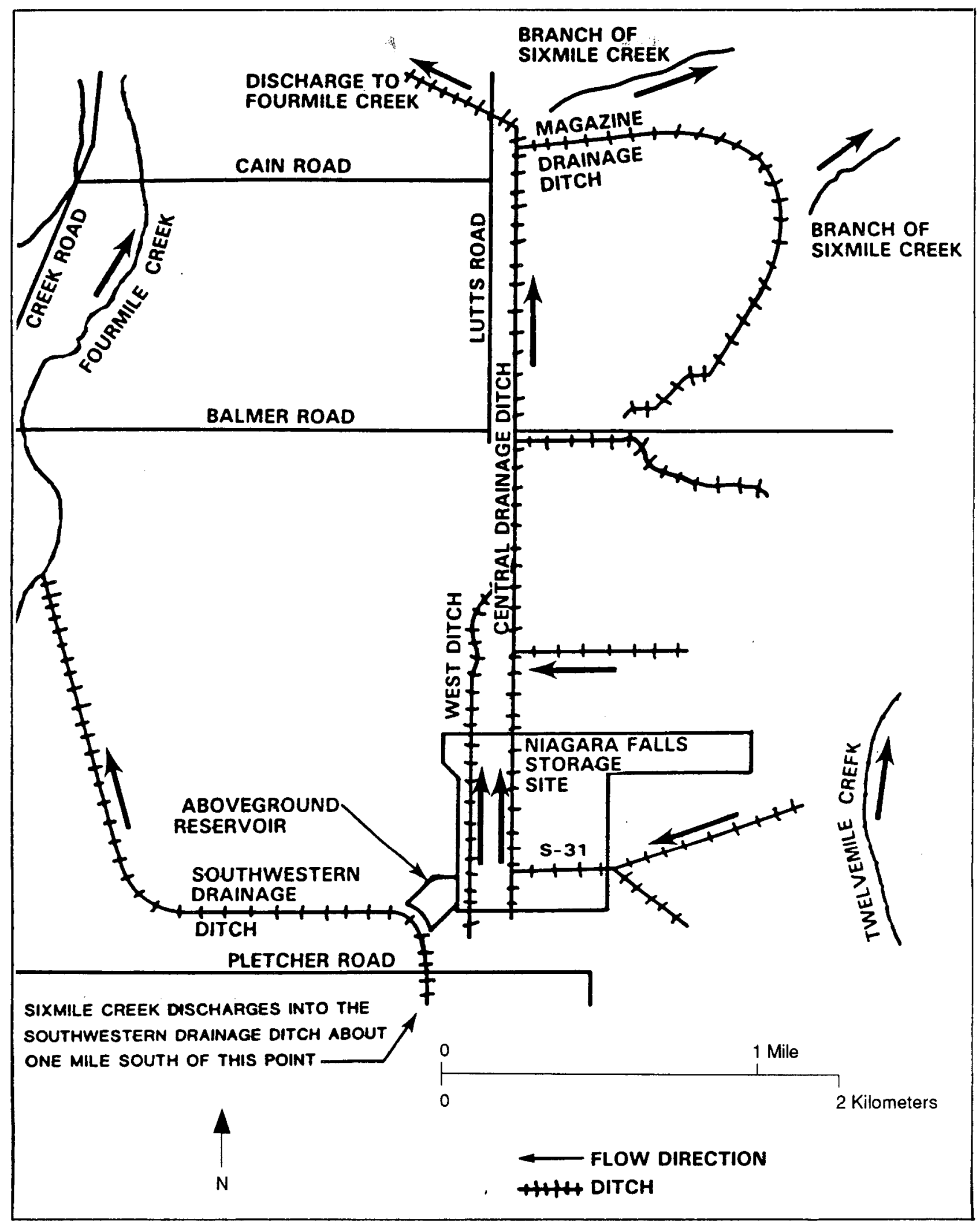

FIGURE 12 Current Drainage Features at NFSS and Surrounding Areas (Source: Adapted from DOE 1986) 
absent, this aquifer is connected with the lower soil aquifer. None of these waterbearing zones is a major aquifer (DOE 1986).

The groundwater from all aquifers underlying the site is of low quality for use as drinking water. Groundwater from the Queenston aquifer is more mineralized than water from the other two aquifers.

The groundwater zones at the NFSS, although not considered as major aquifers, are potentially vulnerable to contamination from the waste stored at the site. This vulnerability is due to the shallow depths of the aquifers and the lack of a continuous, impermeable layer overlying these zones.

\subsubsection{Federally Listed Species and Managed Lands}

The only federally listed species that may occur in the vicinity of NFSS are the bald eagle and peregrine falcon, which would be expected to occur over the area only as occasional transients (Gill 1989). No habitats critical for the survival of these species occur in the site vicinity (see Sec. 2.1.3). No impacts to either species would be anticipated from wastes currently contained at the site or from any further remedial actions that may be taken at the site. No federal lands managed for ecological protection occur within a $3.2-\mathrm{km}(2-\mathrm{mi})$ radius of the site.

\subsection{COLONIE INTERIM STORAGE SITE}

\subsubsection{Setting}

The Colonie Interim Storage Site is located in the town of Colonie, Albany County, New York, just north of the city of Albany (Fig. 13). Land around the site is used for light industrial, commercial, and residential purposes (ANL 1984c).

\subsubsection{Hydrology}

The Colonie site is located within the Patroon Creek drainage basin. A small, unnamed creek traverses a former lake bed on the western edge of the site. The unnamed creek empties into Patroon Creek, which is located about $0.4 \mathrm{~km}(0.25 \mathrm{mi})$ south of the site and flows to the east (Fig. 14). Patroon Creek is not used as a source of drinking water (ANL 1984c).

The bedrock underlying the Colonie site consists of Ordovician shale of the Normanskill formation at a depth of $45-60 \mathrm{~m}(150-200 \mathrm{ft})$ (Bechtel 1984). The Normanskill formation is a relatively impervious rock and yields only about $0.3 \mathrm{~L} / \mathrm{s}$ ( $5 \mathrm{gal} / \mathrm{min}$ ) of water from joints and bedding planes (Heath 1964). The bedrock is overlain by thin layers of glacial till and stratified drift. These glacial deposits are in turn overlain by a layer of clay and silt 30-46 m (100-150 ft) thick (Dineen 1975). 


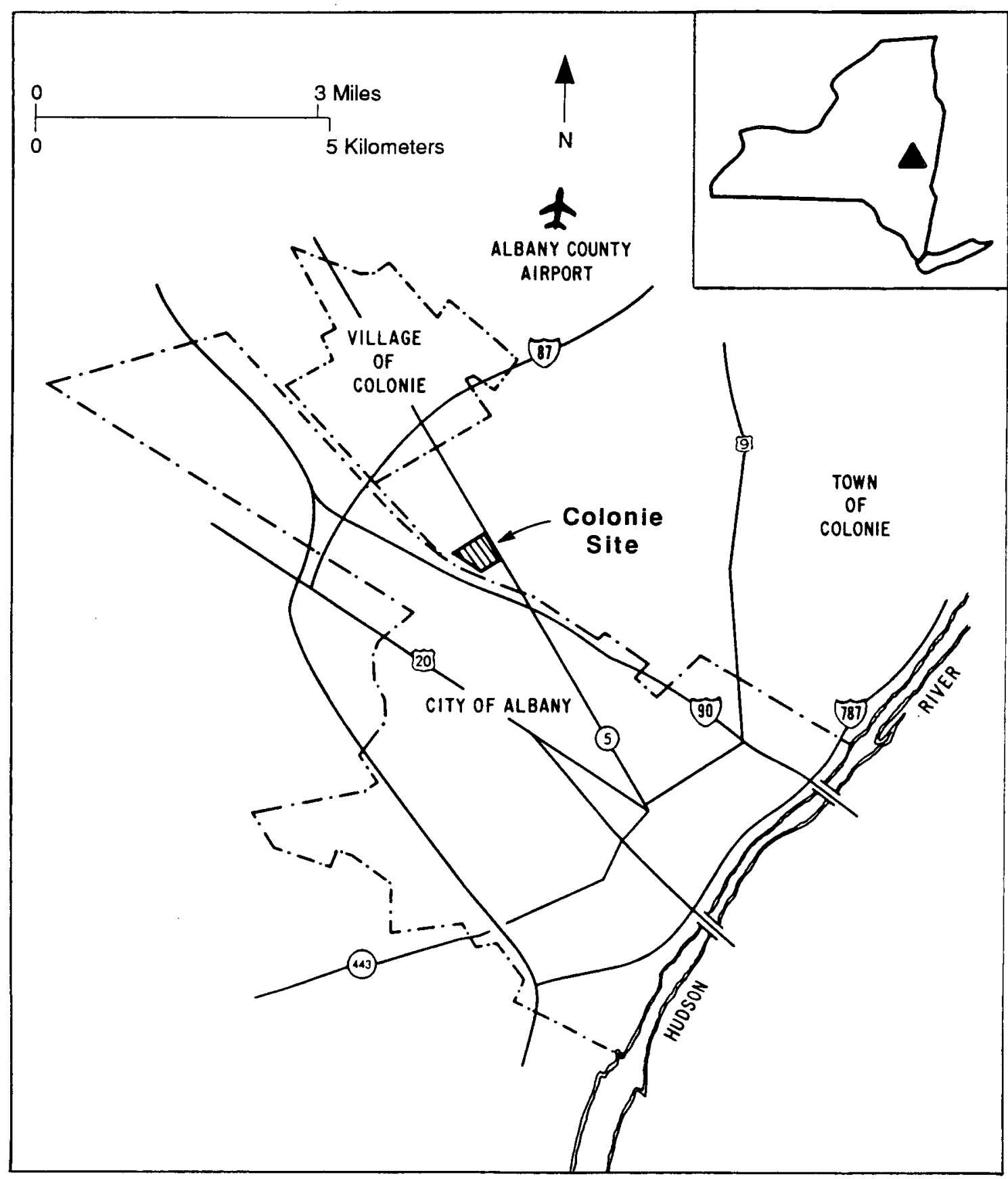

FIGURE 13 Location of Colonie, New York, Site (Source: Adapted from ANL 1984c) 


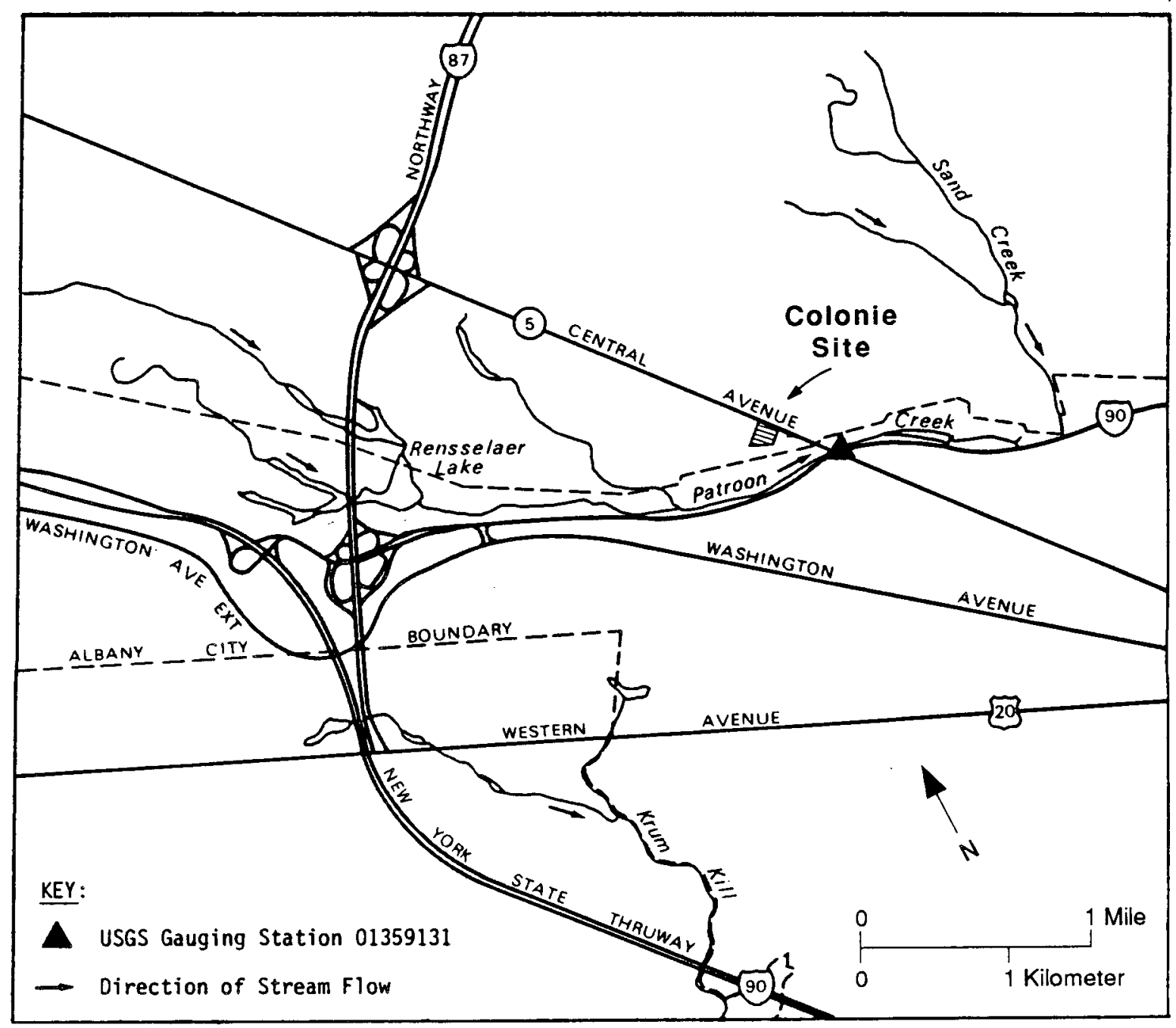

FIGURE 14 Surface Water Drainage in the Vicinity of the Colonie Site (Source: Adapted from ANL 1984c)

Two groundwater units have been identified in the unconsolidated material at the Colonie site -- the upper sands and the lower sands. The two sand units are separated by a clay layer $0.76-3.3 \mathrm{~m}(2.5-10.7 \mathrm{ft}$ ) thick (Bechtel 1985b). The upper sands unit is about $2.4-7.4 \mathrm{~m}(8.0-24.2 \mathrm{ft})$ thick, and the lower sands unit is about $3.4-7.9 \mathrm{~m}$ $(11.0-26.0 \mathrm{ft})$ thick. Field tests indicate that the hydraulic conductivity of the sand layers is on the order of $10^{-4} \mathrm{~cm} / \mathrm{s}\left(10^{-5} \mathrm{in.} / \mathrm{s}\right)($ Bechtel 1985b).

Groundwater in the site area is available in small quantities from bedrock and in moderate to large quantities from unconsolidated surficial deposits. The Ordovician shales yield small amounts of poor-quality water. The water from the glacial deposits has, on the average, a lower mineral content than that from the bedrock (Arnow 1949). Because of the absence of a low-permeability layer above the groundwater units and the 
shallow depth to water, the groundwater appears to be vulnerable to contamination at the Colonie site.

\subsubsection{Federally Listed Species and Managed Lands}

The only federally listed species that may occur in the vicinity of the Colonie site are the bald eagle and peregrine falcon, which would be expected to occur over the area only as occasional transients (Gill 1989). No habitats critical for the survival of these species occur in the site vicinity (see Sec. 2.1.3). Thus, no impacts to either species would be anticipated from wastes currently contained at the site or from any further remedial actions that may be taken at the site. No federal lands managed for ecological protection occur within a $3.2-\mathrm{km}(2-\mathrm{mi})$ radius of the Colonie site.

\subsection{HAZELWOOD AND ST. LOUIS AIRPORT SITES}

\subsubsection{Setting}

The Hazelwood Interim Storage Site (Latty Avenue) is located in Hazelwood, Missouri, about $3.2 \mathrm{~km}(2 \mathrm{mi})$ north of the Lambert-St. Louis International Airport and northeast of the St. Louis Airport Site (SLAPS) in northern St. Louis County, Missouri (Fig. 15). The area near the site is primarily commercial and industrial. The closest residential areas are in Hazelwood, about $0.5 \mathrm{~km}(0.3 \mathrm{mi})$ east. High-density residential areas are located 1.2 and $1.6 \mathrm{~km}(0.75$ and $1 \mathrm{mi})$ east and southeast of the site in Hazelwood and Berkeley, respectively (ANL 1988).

The SLAPS is in the city of St. Louis north of the Lambert-St. Louis International Airport, $24 \mathrm{~km}(15 \mathrm{mi})$ northwest of downtown St. Louis (Fig. 15). Coldwater Creek borders the western end of the site. Land in the area of SLAPS is used for a combination of transportation, commercial, residential, and recreational purposes, or is vacant (ANL 1988).

\subsubsection{Hydrology}

The Hazelwood site is located within the Coldwater Creek drainage basin. Coldwater Creek is about $30 \mathrm{~km}(19 \mathrm{mi})$ long and drains a total area of about $118 \mathrm{~km}^{2}$ $\left(46 \mathrm{mi}^{2}\right)$. The ground surface at the Hazelwood site ranges from about $157 \mathrm{~m}(514 \mathrm{ft})$ MSL near Latty Avenue to about $165 \mathrm{~m}(540 \mathrm{ft}) \mathrm{MSL}$ at the top of the existing contaminated material pile (ANL 1988). The Hazelwood site slopes gently from the pile of contaminated material to the west and south towards Coldwater Creek at an elevation of about $152 \mathrm{~m}(500 \mathrm{ft})$ MSL. Stormwater runoff from the site flows north into a ditch along Latty Avenue and to the south and southwest into another ditch, both of which drain into Coldwater Creek (Fig. 16).

The SLAPS is also located on the eastern bank of Coldwater Creek upstream of the Hazelwood site. Coldwater Creek flows into the Missouri River about $24 \mathrm{~km}$ (15 $\mathrm{mi}$ ) 


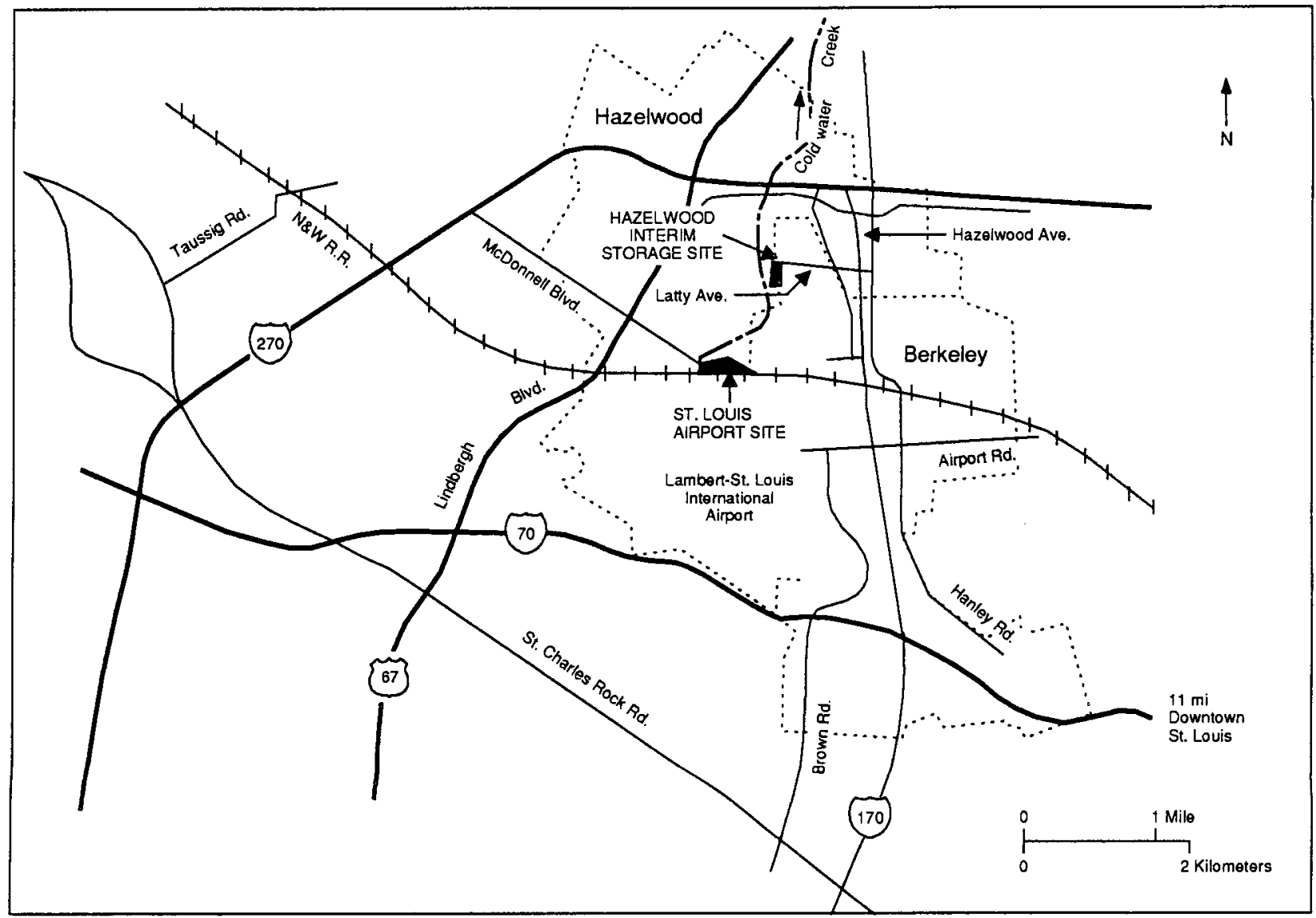

FIGURE 15 Locations of the SLAPS and Hazelwood (Latty Avenue) Sites (Source: Adapted from Bechtel 1986b)

northeast of SLAPS. The surface of SLAPS is $4.5-6.0 \mathrm{~m}(15-20 \mathrm{ft})$ above Coldwater Creek and slopes from east to west at an average grade of $1 \%$. The site surface is generally flat, but because the fill placed over the site in the early 1970s was not compacted and revegetated, differential settling and erosion have resulted in an irregular surface. Surface runoff from SLAPS is intercepted by drainage channels along the northern and southern boundaries of the site. These channels discharge into Coldwater Creek (R.F. Weston Inc. 1980) (Fig. 17).

Most of the wetlands that occurred in the St. Louis area have been drained for mosquito control, agricultural use, urban development, and flood control (Missouri Botanical Gardens 1975). Thus, few potential groundwater discharge areas occur near the sites, except for those associated with Coldwater Creek and its drainages.

The soils in the area consist of a veneer of alluvial deposits from the Mississippi and Missouri rivers - about $1 \mathrm{~m}(3 \mathrm{ft}$ ) of dark silt loam and up to $3 \mathrm{~m}(10 \mathrm{ft})$ of winddeposited silty fine sands and clays (loess) that are underlain by 11-26 $\mathrm{m}$ (35-84 $\mathrm{ft}$ ) of lacustrine sediments. Beneath the lacustrine sediments, the bedrock consists of Pennsylvanian shales and sandstones and Mississippian limestone (Ford, Bacon \& Davis Utah 1978). 


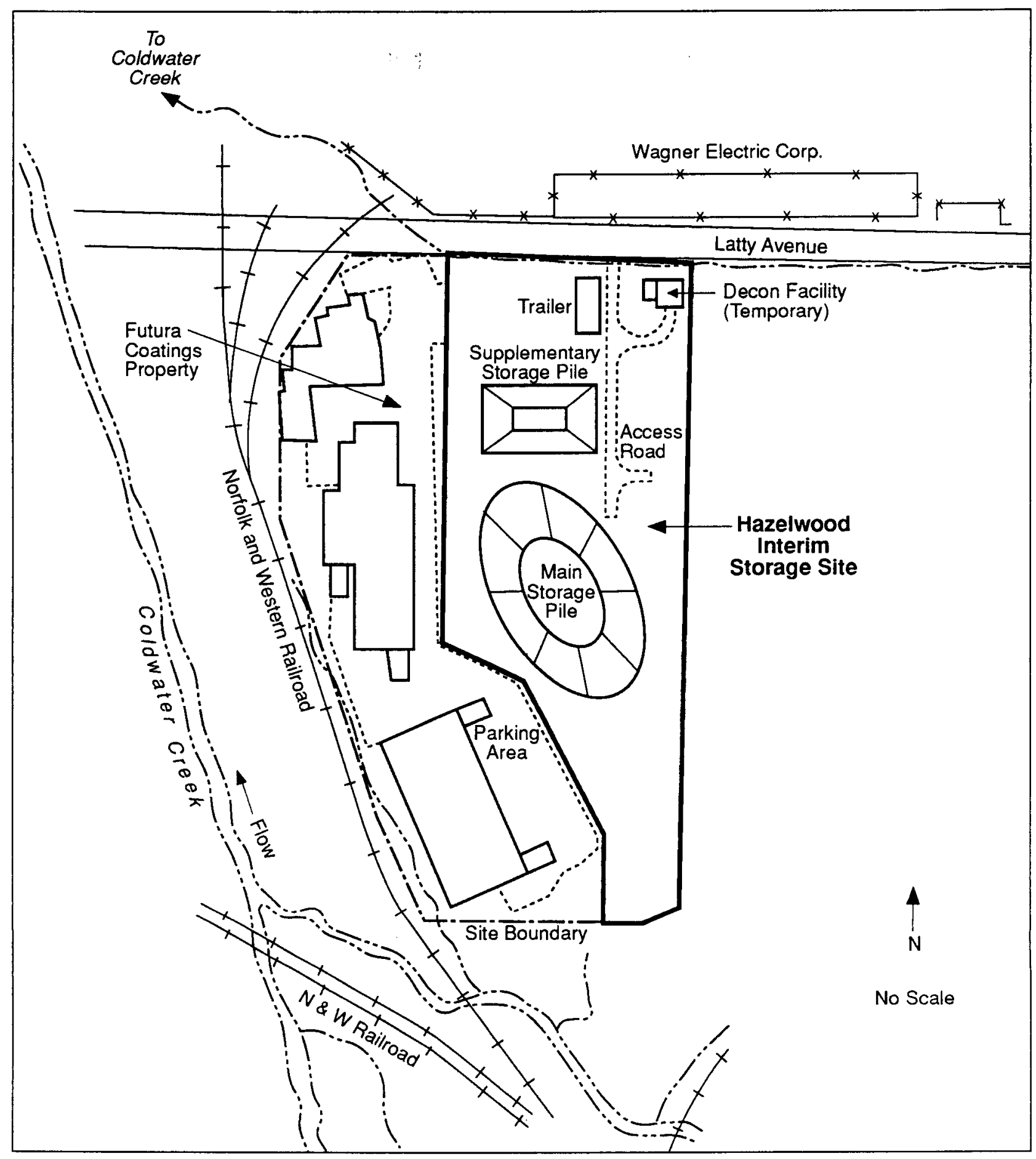

FIGURE 16 Layout of the Hazelwood Site (Source: Modified from Boggs-Mayes and $Y u$ 1989) 


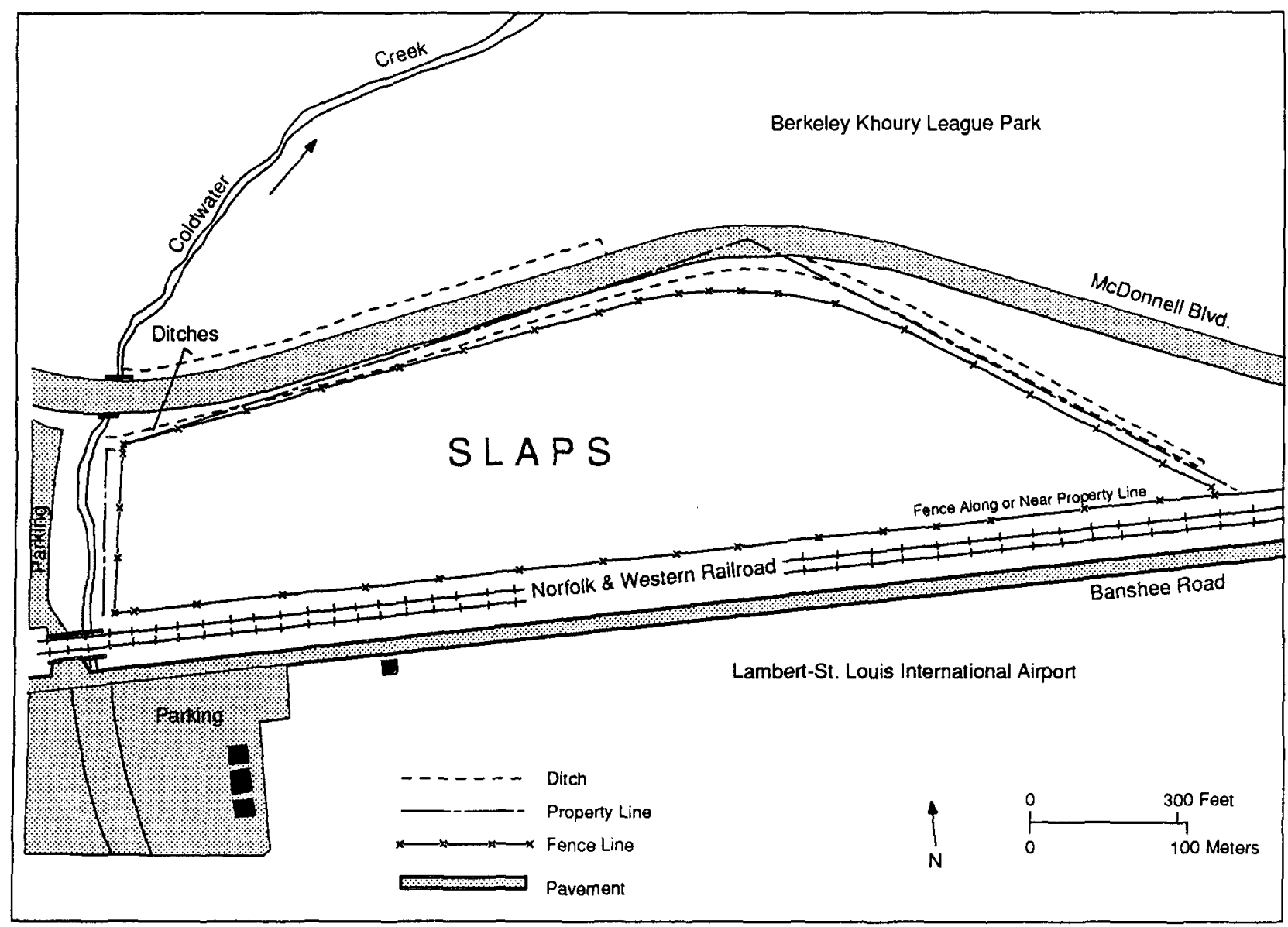

FIGURE 17 Layout of SLAPS (Source: Adapted from Boggs-Mayes and Yu 1989)

Groundwater occurs in the area largely in the unconsolidated deposits and to a much smaller extent in the bedrock. Water from bedrock aquifers is of poor quality. The unconsolidated aquifers are believed to be hydrologically isolated from the bedrock aquifers (Clark and Berven 1984; R.F. Weston Inc. 1982).

The unconsolidated deposits contain two distinct aquifer systems: a shallow unconfined aquifer and a deeper confined aquifer, separated by a clay zone of low permeability. A downward gradient across the clay has been observed (R.F. Weston Inc. 1982); however, because of limited information, the amount of hydrologic interconnection between the two aquifers has not been accurately determined.

Groundwater elevation data show that the predominant direction of flow in both the confined and unconfined aquifers is to the west, with a lesser flow to the north. The upper aquifer is hydraulically connected to Coldwater Creek and, except during periods of flooding, discharges to the creek.

Groundwater at the two Missouri sites is considered vulnerable to potential contamination from the radioactive wastes at the sites. 


\subsubsection{Federally Listed Species and Managed Lands}

The only federally listed species that may occur in the vicinity of the Hazelwood and St. Louis Airport sites is the bald eagle. Although the bald eagle has been observed in St. Louis County, most of these observations have been of migrating and wintering individuals along the Missouri River. Furthermore, there is no critical habitat for the bald eagle within a $3.2-\mathrm{km}(2-\mathrm{mi})$ radius of either FUSRAP site (Tieger 1989). In Missouri, the bald eagle winters near large impoundments and along major rivers, with waterfowl management areas in the northern portion of the state providing important wintering habitat (Nordstrom et al. 1977). Such conditions do not occur in the immediate area of metropolitan St. Louis. Thus, no impacts to bald eagles would be anticipated from wastes currently contained at the sites or from any remedial activities conducted at the sites. No federal lands managed for ecological protection occur within a $3.2-\mathrm{km}$ $(2-\mathrm{mi})$ radius of the Hazelwood or St. Louis Airport sites. 


\section{CONCLUSIONS}

Based on the above evaluations of information on the sites obtained from NEPA and other environmental documentation and information on endangered species and habitats obtained from the open literature, maps, and correspondence with the U.S. Fish and Wildlife Service, it is concluded that no ecologically vital groundwaters exist in the vicinity of any of the nine FUSRAP sites examined. It should be noted that the EPA groundwater classification guidelines have not been finalized. If the definition of ecologically vital groundwaters changes between the draft and final version, a reassessment of this conclusion might be necessary. 


\section{REFERENCES*}

Aller, L., et al., 1987, DRASTIC: A Standardized System for Evaluating Ground Water Pollution Potential Using Hydrogeologic Settings, U.S. Environmental Protection Agency Report EPA/600/2-87/035, Robert S. Kerr Environmental Research Laboratory, Ada, Okla.

ANL, 1984a, Action Description Memorandum, Proposed 1984 Remedial Actions at Wayne, New Jersey, Environmental Research Division, Argonne National Laboratory, Argonne, Ill., July.

ANL, 1984b, Action Description Memorandum, Proposed 1984 Remedial Actions at Middlesex, New Jersey, Environmental Research Division, Argonne National Laboratory, Argonne, Ill., June.

ANL, 1984c, Action Description Memorandum, Proposed FY 1984 Remedial Actions for Vicinity Properties at the Colonie, New York, FUSRAP Site, Environmental Research Division, Argonne National Laboratory, Argonne, Ill., June.

ANL, 1987a, Action Description Memorandum, Interim Remedial Actions at Wayne, New Jersey, Energy and Environmental Systems Division, Argonne National Laboratory, Argonne, Ill., March.

ANL, 1987b, Action Description Memorandum, Interim Remedial Actions at Maywood, New Jersey, Energy and Environmental Systems Division, Argonne National Laboratory, Argonne, Ill., March.

ANL, 1988, unpublished data, Argonne National Laboratory, Argonne, Ill.

Arnow, T.A., 1949, The Ground-water Resources of Albany County, New York, New York State Water Power Control Commission Bulletin GW-20, Albany, N.Y.

Bechtel National, Inc., 1984, Work Plan for the Colonie Interim Storage Site, prepared for U.S. Department of Energy, Oak Ridge Operations Office, Oak Ridge, Tenn.

Bechtel National, Inc., 1985a, Report on Drilling and Well Installations at the Maywood Interim Storage Site, Maywood, New Jersey, prepared for U.S. Department of Energy, Oak Ridge Operations Office Report DOE/OR/20722-75, Oak Ridge, Tenn.

Bechtel National, Inc., 1985b, Report on Drilling and Observation Well Installation at the Colonie Interim Storage Site, Colonie, New York, prepared for U.S. Department of Energy, Oak Ridge Operations Office Report DOE/OR/20722-61, Oak Ridge, Tenn.

*Copies of unpublished correspondence included in this list of references are available upon request from W.S. Vinikour, Argonne National Laboratory, Argonne, Ill. 
Bechtel National, Inc., 1986a, Report on Drilling and Well Installations at the Wayne Interim Storage Site, Wayne, New Jersey, prepared for U.S. Department of Energy, Oak Ridge Operations Office Report DOE/OR/20722-73, Oak Ridge, Tenn.

Bechtel National, Inc., 1986b, Characterization Plan for the Hazelwood Interim Storage Site, prepared for U.S. Department of Energy, Oak Ridge Operations Office Report DOE/OR/20722-106, Oak Ridge, Tenn., Oct.

Bechtel National, Inc., 1988, Environmental Review and Analysis of Select FUSRAP Sites in New York State: A Remedial Investigation/Feasibility Study Work Plan, prepared for U.S. Department of Energy, Oak Ridge Operations Office, Oak Ridge, Tenn.

Bechtel National, Inc., 1989, Middlesex Sampling Plant Annual Site Environmental Report, Middlesex, New Jersey, Calendar Year 1988, prepared for U.S. Department of Energy, Oak Ridge Operations Office Report DOE/OR/20722-214, Oak Ridge, Tenn.

Boggs-Mayes, C., and C. Yu, 1989, Derivation of Uranium Residual Radioactive Material Guidelines for the Three St. Louis FUSRAP Sites: St. Louis Downtown Site, St. Louis Airport Site, and Latty Avenue Properties, Energy and Environmental Systems Division, Argonne National Laboratory, Argonne, Ill., Jan.

Chezik, M.T., 1989, Department of Interior, U.S. Fish and Wildlife Service, letter to W. Vinikour, Energy and Environmental Systems Division, Argonne National Laboratory, Argonne, Ill., March 30. [Reproduced in Appendix to this document.]

Clark, C., and B.A. Berven, 1984, Results of Groundwater Monitoring Program Performed at the Former St. Louis Airport Storage Site for the Period of January 1981 through January 1983, Oak Ridge National Laboratory Report ORNL/TM-8879, Oak Ridge, Tenn., March.

DOE, 1986, Final Environmental Impact Statement, Long-Term Management of the Existing Radioactive Wastes and Residues at the Niagara Falls Storage Site, U.S. Department of Energy Report DOE/EIS-0109F, Washington, D.C.

DeGraaf, R.M., and D.D. Rudis, 1986, New England Wildlife: Habitat, Natural History, and Distribution, U.S. Department of Agriculture, Forest Service, Northeastern Forest Experiment Station General Technical Report NE-108.

Dineen, R.J., 1975, Geology and Land Uses in the Pine Bush, Albany County, New York, New York State Museum Scientific Services Circular 47, Albany, N.Y.

Dowhan, J.J., and R.J. Craig, 1976, Rare and Endangered Species of Connecticut and Their Habitats, State Geological and Natural History Survey of Connecticut, Report of Investigations No. 6.

EPA, 1986, Guidelines for Ground-Water Classification under the EPA Ground-Water Protection Strategy, final draft, U.S. Environmental Protection Agency, Office of Ground-Water Protection, Washington, D.C., Nov. 
Ford, Bacon \& Davis Utah Inc., 1978, Engineering Evaluation of the Latty Avenue Site, Hazelwood, Missouri (Formerly Leased by Cotter Corporation), FB\&DU Report UC-225, prepared for the U.S. Nuclear Regulatory Commission.

Forest Service, 1977, Bald Eagle Habitat Management Guidélines, California Region, U.S. Department of Agriculture, Forest Service.

Gill, W.H., 1989, U.S. Department of Interior, Fish and Wildlife Service, letter to W. Vinikour, Energy and Environmental Systems Division, Argonne National Laboratory, Argonne, Ill., March 27. [Reproduced in Appendix to this document.]

Heath, R.C., 1964, Ground Water in New York, U.S. Geological Survey Bulletin GW-51, prepared in cooperation with the New York Water Resources Commission, Albany, N.Y.

Hovey, G.K., 1988, Bechtel National, Inc., letter to P. Gross, U.S. Department of Energy, Oak Ridge Operations Office, Oak Ridge, Tenn., July 20.

Kulp, C.J., 1986, U.S. Department of the Interior, U.S. Fish and Wildlife Service, letter to Colonel F. Griffis, New York District, U.S. Army Corps of Engineers, May 1.

Missouri Botanical Gardens, 1975, An Introduction to the Biological Systems of the St. Louis Area, Vol. 1, prepared for the East-West Gateway Coordinating Council under contract from St. Louis District, Corps of Engineers, St. Louis, Mo.

Nordstrom, G.R., et al., 1977, Rare and Endangered Species of Missouri, Missouri Department of Conservation and U.S. Department of Agriculture, Soil Conservation Service.

R.F. Weston, Inc., 1980, Evaluation of Environmental Impacts Associated with the Former Airport Storage Site of the Atomic Energy Commission, St. Louis County, Missouri, prepared for the U.S. Department of Energy, Oak Ridge Operations Office, Oak Ridge, Tenn., March.

R.F. Weston, Inc., 1982, Formerly Utilized Sites Remedial Action Program - St. Louis Airport Storage Site (SLAPSS), prepared for U.S. Department of Energy, Oak Ridge Operations Office Report DOE/OR/20722-1, Oak Ridge, Tenn.

Tieger, J., 1989, Department of the Interior, U.S. Fish and Wildlife Service, letter to W. Vinikour, Energy and Environmental Systems Division, Argonne National Laboratory, Argonne, Ill., April 28. [Reproduced in Appendix to this document.]

Wehran Engineering Corp. and RECRA Research, Inc., 1979, Hydrologic Investigation, Seaway Industrial Park Sanitary Landfill, Tonawanda, N.Y. 


\section{DO NOT MICROFILM \\ THIS PAGE}


APPENDIX:

LETTERS OF CONSULTATION 


\section{DO NOT MICROFILM \\ THIS PAGE}




\section{United States Department of the Interior}

FISH AND WILDLIFE SERVICE

P.O. Box 534

705 White Horse Pike

Absecon, New Jersey 08201

(609) 646-9310

March 30, 1989

Mr. William S. Vinikour

Energy and Environmental Systems Division

Argonne National Laboratory

9700 South Cass Avenue

Argonne, Illinois 60439

Dear Mr. Vinikour:

This letter is in response to your March 2, 1989 request to the Fish and Wildlife Service (Service) for information on the presence of federally listed endangered or threatened species within a two-mile radius of the following U.S. Department of Energy Formerly Utilized Site Remedial Action Program sites:

Wayne Interim Storage Site, Wayne, New Jersey;

Maywood Interim Storage Site, Maywood, New Jersey; and,

Middlesex Sampling Plant, Middlesex, New Jersey.

This response is provided pursuant to the Endangered Species Act of 1973 (87 Stat. 884, as amended; 16 U.S.C. 1531 et seq.) to ensure the protection of endangered and threatened species and does not address other service concerns for fish and wildlife resources.

Except for occasional transient species, no federally listed or proposed threatened or endangered flora or fauna are known to exist at either of these sites. Therefore, no further consultation pursuant to section 7 of the Endangered Species Act is required with the Service. Should project plans change, additional information on listed or proposed species become available, or a significant period of time elapses before project implementation, this determination may be reconsidered.

Enclosed is a summary of federally listed and candidate species in New Jersey for your information. Candidate species are those species under consideration by the Service for possible inclusion on the List of Endangered and Threatened Wildlife and Plants. Although these species receive no substantive or procedural protection under the Endangered Species Act, the Service encourages 
the Department of Energy to consider these species in the project planning process. The New Jersey Natural Heritage Program provides the most up-to-date data source for candidate species in the State, as well as maintaining information on state listed species and may be contacted at the following address:

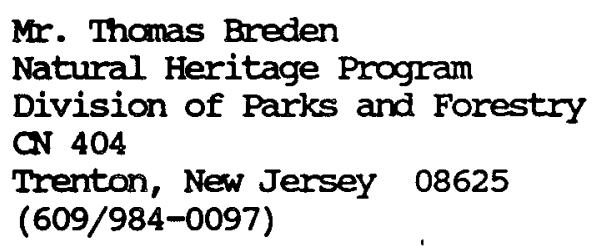

Further information on State listed species may be obtained fran the following office:

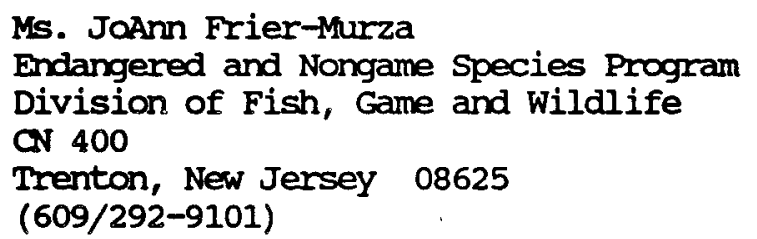

Information contained in this letter and additional information obtained from the aforementioned State sources represents the public interest for fish and wildlife resources and should warrant full consideration in the planning process. The service requests that no part of this letter be taken out of context and if reproduced, the letter should appear in its entirety.

Please contact Lynn Wilson of my staff should you have any questions or require further assistance.

Sincerely,

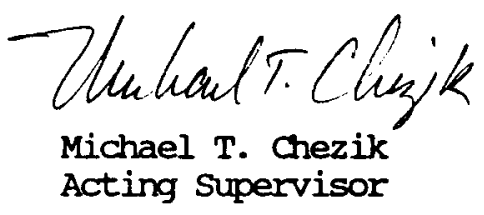

Enclosure 


\section{FEDPRAIIY ENDANGERED AND THIREATENED SPDCIES}

IN NEW JERSEY

An endangered species is any species which is in danger of extinction throughout all or a significant portion of its range.

A threatened species is any species which is likely to become an endangered species within the foreseeable future throughout all or a significant portion of its range.

\section{COMNON NAME}

\section{Fishes:}

Sturgeon, shortnose*

Reptiles:

Turtle, Atl. Ridley* Lepidochelys kempii

Turtle, green*

Turtle, hawksbill*

Turtle, leatherback*

Turtle, loggerhead*

Binds:

Eagle, bald

Falcon, Am. peregrine

Falcon, Artic peregrine

Plover, piping

Tern, roseate
Haliaeetus leucocephalus Falco peregrinus anatum

SCIENIIIFIC NAME

Acipenser brevirostrum

Chelonia mydas

Eretmochelys imbricata

Dermochelys coriacea

Caretta caretta

Falco pereqrimus tundrius

Charadrius melocus Sterma dougallii dougallii

\section{STATUS DISTRTBUTION}

E Hudson, Delaware and Atlantic coastal rivers

E Oceanic, summer resident coastal waters

T Oceanic, summer visitor ccastal waters

E Oceanic, summer visitor coastal waters

E Oceanic, summer visitor ccastal waters

T Oceanic, summer resident coastal waters, rarely nests: Atlantic and Cape May counties

E Entire state

E Entire state, re-establishment to former breeding range in progress

$T$ Entire state migratory

$T$ Entire state

$E$ Entire state 
Nammals:

cougar, eastern

Whale, blue*

Whale, finback*

Whale, humpback*

Whale, right*

Whale, sei*

Whale, sperm*

\section{Plants:}

Pogonia, small whorled

Swanlp pink
Felis concolor couguar

Balaenoptera musoulus

Balaenaotera phisalus

Megaptera novaeanaliae

Balaena glacialis

Balaenoptera borealis

Physeter catodicn

Isotria medeoloides

Helonias burlata
E Entire state, probably extinct

E Cceanic

E Oceanic

E Cceanic

E Coeanic

E Coeanic

E Coanic

E Sussex camty

T Atlantic, Burlington, Camden, Cape May, amberland, Gloucester, Middlesex, Monmouth, Morris, Ccean, and Salem counties

E: endangered species

$T$ : threatened species

* Except for sea turtle nesting habitat, principal responsibility for these species is vested with the National Marine Fisheries Service. 


\section{CANDIDANE SPDCIES IN NEW JERSEY}

Candidate species are species which appear to warrant consideration for addition to the List of Endangered and Threatened Wildlife. Although these species receive no substantive or procedural protection under the Endangered Species Act, the Service encourages federal agencies and other planners to give consideration to these species in the enviromental planning process.

COMYN NAYE

SCIFNIIFIC NAME

STATUS

\section{VERTIEBRATES}

\section{Reptiles:}

Turtle, bog

Terrapin, northern diamondback

snake, northern pine

Birds:

Shrike, migrant loggerhead

Nammals:

Bat, eastern small-footed

Rabbit, New England cottontail

Shrew, long-tailed

Shrew, tuckahoe masked

Woodrat, eastern

\section{INVERTIEBRATTSS}

\section{Draganflies and Damselflies:}

Dragonfly, banded bog skinmer

\section{Beetles:}

beetle, northeastern beach tiger beetle, cobblestone tiger

Butterflies and woths:

butterfly, Mitchell satyr butterfly, regal fritiliary butterfly, tawny crescent moth, Albarufan dagger moth, Bucholz' dart moth, Daecke's pyralid moth, Hebard's noctuid moth, Lenmer's noctuid moth, precious underwing
Clemmys muhlenbergii 2

Malaclemys terrapin terrapin 2

Pituophis melanoleucas melanoleucas

Lanius ludoviciamus miarans

Myotis subulatus leibii 2

Sylvilagus transitionalis $\quad 2$

Sorex dispar $\quad 2$

Sorex cinereus nigriculus 2

Neotama floridana maqister 2
2

Cicindela dorsalis dorsalis 1

Cicindela marainipennis 2

Neonympha mitchelli 2

Speyeria idalia 2

Phyciodes batesi 2

Acronicta albanufa 2

Agrotis bucholzi 2

Crambus daeckeellus 2*

Erythroecia hebardi 2

Lithophane lemmeri 2

Catocala pretiosa 2 
Mussels:

Mussel, dwarf wedge

Alasmidonta heterodon

\section{Plants:}

Beaked-rush, Knieskern's

Rhynchospora knieskernii 1

Bitter cress, Iong's

Candamine longii

Boneset, Pine Barrens

Bulrush, Iong's

Chaffseed

Fern, arly-grass

Grass, sand

Jacob's ladder

Joint-vetch, sensitive

Lobelia, Boykin's

Micranthemum, Nuttall's

Morning-glory, Pickering's

Muhly, Torrey's

Bog asphodel

Panic grass, Hirst's

Pigweed, sea-beach

Pipewort, Parker's

quillwort, Eaton's

Rush, New Jersey

Sedge, Barratt's

Sedge, variable

Spurge, Darlington's

Eupatorium resinosum 2

Scirpus longii 2

Schwalbea americana 2

Schizaea pusilla 2

Calamovilfa brevipilis 2

polemonium vanbruntiae 2

Aeschymomene virginica 2

Lobelia boykinii 2

Micranthemm micranthemoides 1*

Stylisma pickeringii var. pickerigii 2

Muhlenberaia torreyana 1

Narthecium americamum 2

Panicum hirstii 2

Amaranthus pumilus 2

Eriocaulon parkeri 2

Isoetes eatonii 2

Juncus caesariensis 2

Carex barrattii 2

Carex polymorpha 2

Euphorbia purpurea 2

STATUS:

1: Taxa for which the Service currently has substantial information to support the appropriateness of proposing to list the species as threatened or

endangered. Development and publication of proposed rules on these species is anticipated.

2: Taxa for which information now in possession of the service indicates that proposing to list the species as threatened or endangered is possibly appropriate, but for which conclusive data are not available to support proposed rules at this time.

*indicates those species for which there have been no authenticated records in New Jersey since 1963; some of these are possibly extinct, but further research is needed to determine their status with any confidence. 


\title{
United States Department of the Interior
}

\author{
FISH AND WILDLIFE SERVICE \\ औ: 100 Grange Place \\ Room 202 \\ Cortland, New York 13045
}

March 27, 1989

Mr. William S. Vinikour

Environmental Specialist

Energy \& Environmental Systems Div.

Argonne National Laboratory

9700 S. Cass Ave.

Argonne, IL 60439

Dear Mr. Vinikour:

This responds to your March 2, 1989, letter requesting information on Federally listed or proposed endangered or threatened species in the vicinity of the following Department of Energy's Formerly Utilized Site Remedial Action Program sites located in New York:

1. Colonie Interim Storage Site, Albany County

2. Ashland 2, Erie County

3. Seaway Industrial Park, Erie County

4. Niagara Falls Storage Site, Niagara County

The bald eagle, Haliaeetus leucocephalus, and the peregrine falcon, Falco peregrinus, may occasionally transit these areas; other potential occurrences of Federally listed or proposed species within a two-mile radius of the sites are not anticipated. Additional information pertaining to historical records may be obtained by contacting the New York Natural Heritage Program, Wildlife Resources Center, Delmar, NY 12054, telephone $518-439-7488$.

Except for occasional transient individuals, no Federally listed or proposed endangered or threatened species under our jurisdiction are known to exist in the project impact area. Therefore, no Biological Assessment or further Section 7 consultation under the Endangered Species Act (87 Stat. 884, as amended; 16 U.S.C. 1531 et seq.) is required with the Fish and Wildlife Service. Should project plans change, or if additional information on listed or proposed species becomes available, this determination may be reconsidered. A compilation of Federally listed and proposed endangered and threatened species in New York is enclosed for your information.

This response relates only to endangered species under our jurisdiction. It does not address other Fish and Wildlife Service concerns under the Fish and Wildlife Coordination Act or other legislation. 
Please contact Mark Clough of my staff at 607-753-9334 if we can be of further assistance.

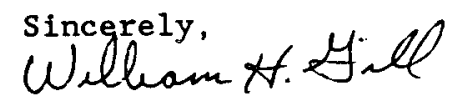

ACTING FOR Leonard P. Corin

Field Supervisor

cc:

NYSDEC, Albany; Buffalo; Olean; Stamford

EPA, NY, NY

EPA, Chief, Marine \& Wetlands Protection Br., NY, NY 
FEDERALLY LISTED AND PROPOSED ENDANGERED AND THREATENED SPECIES IN NEW YORK

Common Name

\section{FISHES}

Sturgeon, shortnose* Acipenser brevirostrum

E

\section{REPTILES}

Turtle, green*

Turtle, hawksbill*

Chelonia mydas

$\mathbf{T}$

Eretmochelys imbricata $\quad E$

Turtle, leatherback*

Turtle, loggerhead*

Turtle, Atlantic ridley*

Dermochelys coriacea

Caretta caretta

Lepidochelys kempii

Haliaeetus leucocephalus Falco peregrinus

E

Eagle, bald

Falcon, peregrine

Plover, piping

Tern, roseate

MAMMALS

Bat, Indiana

Cougar, eastern

Whale, blue*

Whale, finback*

Whale, humpback*

Whale, right*

Whale, sei*

Whale, sperm*
Charadrius melodus

Sterna dougallii dougallii
E

T

E

Myotis sodalis

Felis concolor cougar $\quad$ E

Balaenoptera musculus

Balaenoptera physalus Megaptera novaeangliae Eubalaena glacialis Balaenoptera borealis Physeter catodon
Distribution

\author{
Hudson River \& other \\ Atlantic coastal rivers \\ Oceanic sumner visitor \\ coastal waters \\ Oceanic summer visitor \\ coastal waters \\ Oceanic summer resident \\ coastal waters \\ Oceanic summer resident \\ coastal waters \\ Oceanic summer resident \\ coastal waters
}

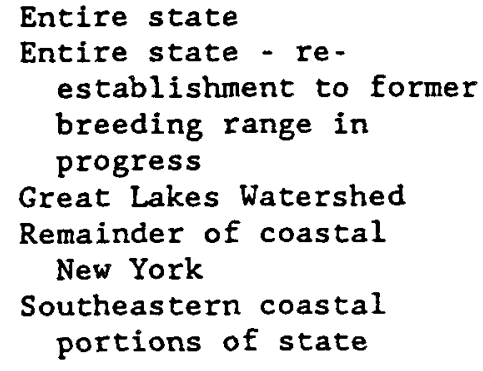

* Except for sea turtle nesting habitat, principal responsibility for these species is vested with the National Marine Fisheries Service.

Region $5-3 / 2 / 89-2$ pp. 
FEDERALLY LISTED AND PROPOSED ENDANGERED AND THREATENED SPECIES IN NEW YORR (Cont'd)

Common Name

$\frac{\text { MOLLUSKS }}{\text { Snail, Chittenango }}$
ovate amber
$\frac{\text { PLANTS }}{\text { Monkshood, northern }}$
wild
Pogonia, small
whorled
Swamp pink
Gerardia, sandplain
Fern, American
hart's-tongue
Orchid, eastern
prairie fringed

Scientific Name

Status

$\frac{\text { Succinea }}{\text { chittenangoensis }}$

Aconitum noveborancense $T$

Isotria medeoloides

Helonias bullata

Agalinis acuta

Phyllitis scolopendrium var. americana

Platanthera leucophea
$\mathrm{T}$

E

$\mathbf{T}$

$\mathbf{E}$

Proposed $\mathrm{T}$

Proposed $\mathrm{T}$
Distribution

Madison County

Ulster County

Entire state

Staten Island - presumed extirpated

Nassau and Suffolk Counties

Onondaga and Madison Counties

Not relocated in New York 


\title{
United States Department of the Interior
}

\author{
FISH AND WILDLIFE SERVICE \\ COLUMBU FIELD OFFICE (ES) \\ P.0. Box 1508 \\ Columbia, Missouri 65205
}

IN REPLY REFER TO:

April 28, 1989

Mr. Bill vinikour

Environmental Scientist

Energy and Environmental Systems Division

Argonne National Laboratory

9700 South Cass Avenue

Argonne, Illinois 60439

Dear Mr. Vinikour:

This letter is in reference to the Department of Energy's groundwater study of Formerly Utilized Site Remedial Action Program (FUSRAP) sites located at the st. Louis Airport and Latty Avenue in Hazelwood, st. Louis County, Missouri. This letter provides comment only on the endangered species aspect of the project. Comments on other aspects of the project under the authority of the provisions of the Fish and Wildlife Coordination Act (16 U.S.C. 661 et. Seq.) will be sent under separate cover.

\section{Endangered Species Comments}

Under Section 7 (c) of the Endangered Species Act, Federal agencies are required to obtain from the Fish and wildlife service information concerning any species, listed or proposed to be listed, which may be present in the area of a proposed action. Therefore, we are providing you with the following list of species which may be present in the concerned area:

Endangered

Bald eagle

(Haliaeetus leucocephalus)

There is no designated critical habitat in the project area.

The bald eagle has been sighted in st. Louis County. However, most of these were migrating and wintering along the Missouri River. Therefore, the project will not affect the bald eagle. 
If you have any questions regarding this response or if we can be of any further assistance, please contact Dr. Mamie A. Parker, Columbia Field office, P.O. Box 1506, Columbia, Missouri 65205 (314) $875-5374$ or (FTS) 276-5374 .

sincerely yours,

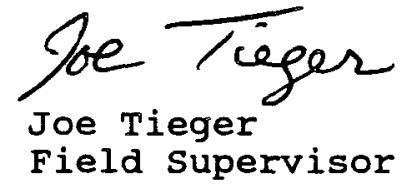

MAP : mb : wp : 1130SLDOEIXA 